\title{
ע Romanikielinen ja romanikieleen pohjautuva aines Suomen romanien suomenkielisessä verkkokeskustelussa
}

\author{
MirkKa SALO
}

\section{Johdanto}

Tarkastelen tässä artikkelissa Suomen romanien suomenkielisessä verkkokeskustelussa esiintyvää romanikielistä ainesta. Keskityn Suomen romanikieleen perustuvaan sanastoon ja tutkin esimerkiksi sitä, mitä sanaluokkia aineistossa esiintyvät lekseemit edustavat, millaisia ne ovat etymologialtaan ja miten suomea ja romanikieltä yhdistetään. Termillä romanikielinen tarkoitan tässä romanikielen kieliopin mukaan taivutettuja Suomen romanikielen sanoja, termillä romanikieleen pohjautuva puolestaan romanikielisiä aineksia sisältäviä mutta suomen kieliopin mukaisesti taivutettuja sanoja. Jälkimmäiseen ryhmään kuuluvat myös ne johdokset ja yhdyssanat, jotka sisältävät sekä romanikielisiä että suomenkielisiä aineksia. Tutkimassani aineistossa esiintyy myös muita romanikielen murteita, kuten Itä-Slovakian romania, kalderašia, lovaria sekä Ruotsissa puhuttavaa Suomen romanikielen muotoa eli Ruotsin káloa. ${ }^{1}$ Niitä esiintyy kuitenkin lähinnä romanikielisissä lauseissa, ja niiden käyttö on muutenkin keskustelupalstalla marginaalista, eikä niitä sisältäviin viesteihin yleensä vastata aineiston keskusteluissa. Huomioni kohdistuukin näin vain Suomen romanikieltä edustaviin tai siihen pohjaaviin ilmauksiin.

Tutkimukseni edustaa teknologisissa ympäristöissä tapahtuvan vuorovaikutuksen tutkimusta, josta Ilkka Arminen (2016) käyttää termiä medioitu vuorovaikutus (ks. myös Helasvuo, Johansson \& Tanskanen 2014). Artikkeli kuuluu variaationtutkimuksen alaan ja sen piirissä erityisesti lainaamisen ja koodinvaihdon tutkimukseen. Se on myös osa romanitutkimusta (ks. esim. Idäntutkimus 2015). Ensimmäinen tunnettu julkaisu Suomen romanien kielestä on 1700-luvulta (Ganander 1780), mutta laajemmin tutkimusta on alkanut ilmestyä vasta 2000-luvulla. Tutkimuksen kohteena ovat olleet erityisesti Suomen romanikielen attritio (ks. Vuorela \& Borin 1998;

1. Esimerkkinä Itä-Slovakian romanista laulun sanat: Ausvicate hi kher bro / Odoj besel mro pirano / Besel, besel gondolinel / Te pre mande pobisterel / O tu kalo cirikloro. Ruotsissa puhuttavaa káloa edustaa seuraava lause: jakhes me phenjom, nebi džaná, te tut ná phenjas i romni 'niin minä sanoin, mutta en tiedä/tiennyt, että romaninainen ei tuntenut sinua'. 
Granqvist \& Pirttisaari 2003; Pirttisaari 2002, 2004; Granqvist 2013a, 2013b: 180-188) sekä koodinvaihto suomen ja romanikielen välillä (ks. Kovanen 2010, 2013; Adamou \& Granqvist 2015). Myös Suomen romanien diskurssia on tutkittu (Granqvist 2009). Nämä aiemmat tutkimukset antavat mahdollisuuden verrata verkkokeskustelujen kieltä romanien puheesta tehtyihin havaintoihin. Tutkimuksellani on myös liittymäkohtia Suomen muiden vähemmistökielten (ks. esim. Muir 2009, 2013) sekä slangien tutkimukseen (ks. esim. Lipsonen 1990; Paunonen 2006, 2017).

Olen julkaissut aiemmin saman aineiston pohjalta artikkelin, jossa tarkastelen romanikielisten lainasanojen ja koodinvaihdon tehtäviä verkkokeskustelussa (Salo 2016). Tässä artikkelissa puolestaan tutkin sitä, onko romanikielisten sanojen käyttö samanlaista anonyymissa verkkokeskustelussa kuin puhutussa keskustelussa ja millaista tämä romanikielinen aines tarkemmin ottaen on. Kun kyse on suullisesta vuorovaikutuksesta, romanikielisten elementtien (romanikielisten sanojen, romanikieleen pohjautuvien sanojen, romanikielen kieliopillisten rakenteiden ja pitempien romanikielisten jaksojen) käyttö riippuu sekä keskustelutilanteen osallistujista, kuten pääasiallisesta keskustelukumppanista, että puheenaiheesta (ks. alalukua 1.1). Osaa sanastosta käytetään tyypillisesti romanien keskinäisessä keskustelussa. Tätä havainnollistaa lause se on Marian däi 'se on Marian äiti', jossa sanaa däi 'äiti' on käytetty ilmeisesti kulttuurisista syistä. Suomen romanit nimittäin välttävät biologisesta vanhemmuudesta kertovia sanoja. Koodinvaihto juuri tässä sanassa on keino kiertää aihe symbolisesti (vrt. Granqvist \& Viljanen 2002). Kyseinen esimerkki on kuultu bussissa Helsingissä (15.10.2009), ja se oli osa puhelinkeskustelua, joka oli ilmeisesti romanien välinen, koska siinä keskusteltiin romanikulttuurille tyypillisistä aiheista. Romanikieleen liittyvien sanojen käyttö voi selittyä myös sillä, että paikalla on pääväestön edustajia. Joskus kuulee käytettävän romanikieleen perustuvia sanoja esimerkiksi, kun keskustelu koskee huumeita, romanikielellä dramb-i-t (< dramb 'lääke'; keskustelu raitiovaunussa Helsingissä 3.4.2016). Romanikieleen perustuva sana lansa-ta (< lans- 'osoittaa kunnioitusta, hävetä) puolestaan edustaa romanikulttuurin termejä, joita ei voi ilmaista suomen yleiskielisellä vastineella merkityksen muuttumatta (Salo 2016: 260-263).

Oma aineistoni on siis verkkokeskusteluista. Verkkokeskustelussa keskustelijan ei tarvitse paljastaa henkilöllisyyttään eivätkä kirjoittajan etniset piirteet ja muut tunnusmerkit ole nähtävissä muille keskustelijoille. Oletuksenani oli kuitenkin, että tutkimusaineistona olevan keskustelupalstan romanikielisten sanojen käyttö muistuttaisi romanikielisten sanojen käyttöä romanien keskinäisissä suomenkielisissä puhutuissa keskusteluissa, koska palsta on tarkoitettu nimenomaan romaneille ja kyseiset keskustelut ovat hyvin vapaamuotoisia.

Tutkimuskysymykseni on, millaisia romanikielen elementtejä nykypäivän suomenkielisessä verkkokeskustelussa käytetään. Analysoin aineistoa sekä laadullisesti että määrällisesti. Tarkastelu valaisee sitä, mille romanikielen sanoille on käyttötarvetta verkkokeskustelussa ja millainen romanikielinen sanasto on keskeistä näissä keskusteluissa. Tarkastelen myös lekseemien etymologiaa ja vertaan Suomen romanien verkkokeskustelussa käyttämää kieltä niin sanottuihin pararomaneihin (ks. tarkemmin lu-

2. Esimerkeissä romanikielinen aines on merkitty lihavoinnilla. 
kua 6). Pararomaneilla tarkoitetaan kielimuotoja, joissa on alueen valtaväestön kielen rakenne ja romanikielestä on säilynyt lähinnä vain sanastoa, esimerkkinä angloromanista they're vel-lin ( $<v$ - 'tulla') 'he tulevat' (Matras, Gardner, Jones \& Schulman 2007: 34-35). Pararomaneita ovat esimerkiksi Britannian angloromani, Skandinavian skandoromani ja Iberian niemimaalla puhuttavat pararomanit (ks. Matras ym. 2007; Bakker 1995; Etzler 1944; Granqvist 2013b). Seuraavassa alaluvussa esittelen hieman tarkemmin aiempaa tutkimusta romanikielestä ja romanikielisistä puhutuista keskusteluista, joihin vertaan tutkimustuloksiani verkkokeskustelun kielestä. ${ }^{3}$

\subsection{Romanikieli ja Suomen romanien etnolekti}

Romanikielen juuret ovat Intian alueella muinoin puhutuissa ja kirjoitetuissa kielissä, kuten sanskritissa ja prakritissa. Romani onkin sukua hindille ja useille muille Intian alueen kielille (esim. Vuorela \& Borin 1998: 60; Thesleff 1911: 82). Vanhimmat ainekset ovat esiarjalaisista kielistä (Valtonen 1972), mutta romanikielessä on myös pitkältä ajanjaksolta eri vaiheissa omaksuttuja lainasanoja. Näiden kielellisten vaikutteiden perusteella on päätelty romanien vaellusreittejä Intian alueelta aina Euroopan eri osiin (Vuorela \& Borin mas. 52; Valtonen 1968: 126). Suomen romanikielen sanojen alkuperää ovat tutkineet erityisesti Bertil Tikkanen (esim. 2013) ja aiemmin Pertti Valtonen, joka on laatinut esimerkiksi vuonna 1972 ilmestyneen romanikielen etymologisen sanakirjan.

Suomen romanikieli on elänyt suhteellisen eristettynä Suomen alueella. Historiallisten lähteiden mukaan romaneita on saapunut tänne 1500-luvulta alkaen (Pulma toim. 2006: 23). Uusia romanisukuja on tullut asuttamaan Suomea todennäköisesti vielä 1800-1900-lukujen vaihteessa tälllä vierailleiden Etelä- ja Itä-Euroopan romaneiden joukosta (Granqvist, henk.koht. tiedonanto 20.4.2017). Jo Gananderin (1780) kuvauksesta on havaittavissa Suomen romanikielen eriytyminen muista romanimurteista sekä suomen vaikutus sen sanastoon ja fonologiaan. Varsinkin 180o-luvun puolivälistä lähtien Suomen romanikieleen on kehittynyt muista Euroopan romanimurteista poikkeavia piirteitä romanien omaksuttua esimerkiksi ääntämiseen ja kielioppiin vaikutteita suomesta (esim. Vuorela \& Borin 1998: 68-72; Granqvist 2013a: 112; Valtonen 1968: 40). Vuorelan ja Borinin (mas. 63) mukaan suomen vaikutus näkyy Suomen romanikielessä nykyään kaikilla kielen tasoilla. Siitä puuttuvat puheen eri tyylilajirekisterit ja eri yhteiskuntaluokkien kielenkäyttöä erottavat piirteet (Granqvist 2013a: 120, 129; vrt. Vuorela \& Borin mas. 69), mutta sen käytössä on paljon yksilöllistä vaihtelua niin sanojen taivutuksessa, kieliopillisissa rakenteissa kuin äänne- ja kirjoitusasussakin. Yksilömurteiden variaatiota ovat lisänneet Suomen romanikielen morfosyntaktisen kehyksen rapautuminen ja romanikielen vähäinen käyttö (esim. Granqvist mas. 120, 142).

Seuraavaksi tarkastelen Suomen romanien tämänhetkistä suomen kielen varieteettia, jota kutsun nimellä etnolekti (ethnolect). Etnolektillä tarkoitetaan yleensä jonkin vähemmistöryhmän käyttämää valtakielen tai jonkin muun kielen varieteettia

3. Kiitän arvioijia tarkkanäköisistä kommenteista, jotka ovat auttaneet minua parantamaan käsikirjoitusta. 
(esim. Muysken \& Rott 2013; Sollid 2013). Suomen romanien käyttämälle etnolektille on ominaista, että se sisältää romanikielestä periytyneitä kielellisiä elementtejä.

Suomen romanit, jotka ovat nykyään ensikieleltään suomenkielisiä4 (Hedman 2009), käyttävät tilanteesta riippuen suomen yleis- tai puhekieltä tai tätä etnolektiksi nimettyä omaa suomen varieteettiaan. Suomenkielisissä keskusteluissaan he käyttävät usein yksittäisiä romanikielisiä ja romanikieleen perustuvia sanoja. Tämä on helposti havaittavissa, jos kuulee romaniryhmän kasvokkaista keskustelua tai romanien välisiä puhelinkeskusteluja. On esitetty, että romanikieleen perustuvaa sanastoa käytetään erityisesti romanikulttuuriin liittyvistä syistä, kuten puhtaus- ja häveliäisyyssäännöstöä käsittelevissä puheenaiheissa (Granqvist 2009; Granqvist \& Viljanen 2002) tai etnisen identiteetin ilmaisemiseen (Åkerlund 2004). Nuorten romanien keskustelussa romanikieltä sisältävä suomi voi toimia keinona ilmaista romani-identiteettiä samalla tavoin kuin romanikielen käyttö vanhemmilla sukupolvilla (Åkerlund 2004: 238). Keskustelun sisällön salaamiseksi jotkin sanoista voidaan vaihtaa romanikielisiksi myös siksi, että paikalla on lapsia tai muita kuin romaneita (Hedman 2004, 2009).

Suomen romanien keskusteluissa esiintyy koodinvaihtoa romanikielelle myös pidempien ilmausten ja jaksojen muodossa (ks. Vuorela \& Borin 1998: 62-63). Koodinvaihdolla (code switching) tarkoitetaan sitä, että puhuja vaihtaa käyttämäänsä kieltä saman keskustelun aikana; tämä pätee sekä puhuttuun että kirjoitettuun keskusteluun (ks. esim. Auer 1999; Kalliokoski 1995; Meakins 2013; Myers-Scotton 2002; Poplack 1980, 2004). Matriisikieleksi kutsutaan sitä kieltä, joka on monikielisen keskustelun hallitseva kieli (ks. Myers-Scotton 2002: 9). Romanien keskustelussa se on useimmiten suomi, jossa on kuitenkin siinä määrin omia erityispiirteitään, että sitä voi luonnehtia etnolektiksi. Kuten romanikieltä myös romanien etnolektia esiintyy tilanteissa, joissa etnisen ryhmäidentiteetin rooli on keskeinen, esimerkiksi tähän tapaan: laittasvat vaan kaajeen koolat oisvat omia itteään 'laittaisivat vaan valkolaisvaatteet, olisivat omia itsejään' (vrt. Clyne, Eisikovits \& Tollfree 2002: 147). Suomen romanien suomen kieleen tuovat omaleimaisuutta muutkin piirteet kuin sanasto: prosodia, joka poikkeaa valtaväestön käyttämästä (painon ja korkeuden vaihtelu, äänteiden kestoilmiöt, tauotukset yms.), ja joidenkin suomenkielisten sanojen käyttö eri merkityksessä kuin muilla Suomen etnisillä väestöryhmillä, esimerkiksi toiset merkityksessä 'vanhemmat' ja mökille merkityksessä 'kotiin' (vrt. Granqvist \& Viljanen 2002; Hedman 2009; Salo 2016: 252, 261).

Puhutuissa keskusteluissa romanikielisiä ja romanikieleen pohjautuvia sanoja käytetään joko romanikielen tai suomen mukaan taivutettuina. Esimerkiksi poikaa hunka-ttiin (< hunkav- 'hakata'). Kielten rinnakkainen käyttö ilmenee myös johdosten ja yhdyssanojen muodostuksessa sekä pitempinä koodinvaihtojaksoina. Suomen kielen vaikutuksesta romanikieleen kertoo esimerkiksi se, että joskus käytetään lukusanojen yhteydessä yksikkömuotoa monikon sijasta, kuten esimerkissä saatto olla deh-ki gräi ('kymmenen-kin hevonen.SG'5; Kovanen 2013: 209). Vaikutus ilmenee myös toisin päin: toisinaan suomenkielisiä sanoja taivutetaan romanikielen mukaan. Romanikielen taito

4. Pieni osa on ruotsinkielisiä.

5. Kielenainesten merkinnässä käytetyt sekä artikkelin taulukoissa esiintyvät lyhenteet on koottu liitteeseen (s. 562-564). 
on Suomessa harvinaista muilla etnisillä ryhmillä, joten romania voidaan käyttää salakielen funktiossa. Romanikielisten sanojen ja jaksojen käyttö keskustelussa liittyykin tilanteisiin, joissa on otettava huomioon toiset paikalla olevat romanit esimerkiksi kulttuurisista syistä (esim. eri ikäluokkien väliseen käyttäytymiseen liittyvät seikat) tai joissa paikalla on sekä romaneja että muita ja viesti tahdotaan välittää vain romaneille (Granqvist 2009; Granqvist \& Viljanen 2002; Hedman 2004, 2009). Romanikielisten elementtien käytölle ei ole sen sijaan yleensä tarvetta silloin, kun romanit haluavat viestiä pelkästään muille kuin romaneille.

\subsection{Aineisto ja menetelmät}

Aineistona on verkkokeskustelupalsta Suomi24.fi-romano, jonka sisällön olen tallentanut kokonaisuudessaan hieman yli kymmenen vuodelta ajalta (22.2.2003-18.7.2013), palstan aloitusvuodesta lähtien. Korpus on itse keräämäni; tiedonlouhinnassa sain merkittävää apua Jan Guillénilta. Suomi24.fi-verkkoyhteisössä on useita keskustelupalstoja erilaisille ryhmille ja kiinnostuksen kohteille. Keskusteluympäristö on epävirallinen, arkinen sekä asynkroninen, eli keskustelijat eivät välttämättä kirjoita kommentteja samaan aikaan. Suomi24.fi-romano on suunnattu romanien väliseen keskusteluun (Suomi24.fi-Romano 2016), mutta foorumi on kaikille avoin.

Teknologinen keskusteluympäristö asettaa keskustelijan erilaiseen identiteettiasemaan kuin puhuttu keskustelu (Arminen 2016: 179; Woolgar 1991). Palstalle kirjoittava voi viestiä anonyymisti ilman, että hänen etnistä identiteettiään tiedetään. Tosin haastattelemieni asiantuntijoiden mukaan romanien on toisinaan helpompaa kuin valtaväestön edustajien tunnistaa toinen kirjoittaja romaniksi pelkkien viestin tyyliseikkojen perusteella, vaikka viestissä ei olisikaan romanikielisiä elementtejä (Päivi Majaniemi ja Tiina Pirttilahti, henk.koht. tiedonanto 14.5.2013). Yleisesti voi todeta, että palstalla käytetty suomen kieli poikkeaa monessa suhteessa suomen yleiskielestä lauserakenteiden ja välimerkkien osalta, ja siinä on paljon puhekielen piirteitä. Romanikielisillä elementeillä tarkoitan romanikielisiä sanoja, taivutusmuotoja ja jaksoja sekä romanikieleen pohjautuvia, suomen kieliopin mukaan taivutettuja sanoja.

Kokonaisuudessaan aineisto sisältää laajuuteensa nähden vähän romanikielisiä elementtejä. Niitä käytetään ennen kaikkea romani-identiteetin ilmaisemiseen, kun anonyymi keskusteluympäristö ei sitä paljasta (Salo 2016). Palstalle ei tarvitse rekisteröityä, joten jokaisen viestin voi kirjoittaa eri nimimerkillä tai ilman nimimerkkiä. Osa viesteistä on kirjoitettu pysyvällä nimimerkillä tai sillä kutsumanimellä, jota kirjoittaja käyttää omien havaintojeni mukaan reaaliympäristössäkin. Näiden osallistujien osalta verkkokeskustelu muistuttaa tilannetta, jossa keskustelijoiden henkilöllisyys tiedetään - tosin useampi voi käyttää samaa nimimerkkiä. Jotkut keskustelijat arvioivat ja arvostelevat viesteissään varsinkin vakituisia nimimerkkejä käyttäviä kirjoittajia kyseenalaistaen, ovatko he aitoja romaneja. Epäilyksensä he perustavat kommentteihin, jotka kyseiset nimimerkit ovat kirjoittaneet. Joskus myös keskustelijan kirjoitustyylin perusteella arvioidaan sitä, onko hän romani. Suuri osa viesteistä on kuitenkin kirjoitettu väliaikaisella nimimerkillä tai ilman nimimerkkiä. Tällöinkin keskustelija ilmaisee usein romani-identiteettinsä, vaikka ei paljasta henkilöllisyyttään. 
Keskustelupalsta on suomenkielinen ${ }^{6}$, mutta sille kirjoitetaan myös täysin romanikielisiä viestejä. Palstalle on lähetetty lisäksi useita muita kieliä (esim. englantia, espanjaa ja ranskaa) sisältäviä viestejä. Siellä on myös pitkiä suomenkielisiä viestiketjuja, joiden sisältö ei käsittele romaneita vaan esimerkiksi Suomessa asuvien venäläisten kokemuksia ja näkemyksiä suomalaisista. Toisaalta palstalla on myös paljon romaneille suunnattuja viestejä, joiden kirjoittaja ilmoittaa edustavansa valtaväestöä. Nämä kaikki tekijät vaikuttavat osaltaan romanikieltä sisältävän suomenkielisen keskustelun määrään.

Artikkelini on aineistolähtöinen ja perustuu aineiston laadulliseen ja määrälliseen analyysiin. Aineistossa on yhteensä 6784434 sanaesiintymää. Keräsin siitä aluksi romanikieliset tai romanikieleen pohjautuvilta vaikuttavat sanat ja analysoin ne lauseyhteydessään niiden kielen varmistamiseksi. Esimerkkinä tämän työvaiheen löydöistä on sane sika, joka esiintyy aineistossa romanikielen imperatiivina merkityksessä 'näytä' kaksi kertaa ja suomenkielisenä substantiivina (eläinlaji / ihmisen nimittely) 113 kertaa. Tarkastin kustakin romanikielisestä tai romanikieleen pohjautuvasta saneesta, esiintyykö se suomenkielisessä vai romanikielisessä lauseessa. Varmistin vielä lauseen, virkkeen tai kommentin matriisikielen. Myös romanikielisten taivutusmuotojen esiintyessä tarkastin matriisikielen. Päätin jättää nimimerkit pois laskiessani kokonaissanemäärää; sama koskee viestien otsikoita. Tämän vuoksi vain itse viesteissä olevat romanikieliset saneet on huomioitu laskelmissa. Toisaalta otsikoissa ja nimimerkeissä ei esiinny sellaisia sanoja, joita ei olisi viesteissä.

Tutkimukseni kohteena ovat siis suomenkielisissä lauseissa käytetyt Suomen romanikieliset ja romanikieleen pohjautuvat ilmaukset. Artikkelini rakentuu seuraavasti: Luvussa 2 kuvaan sitä, miten aineistossa esiintyvät lekseemit jakautuvat eri sanaluokkiin ja mikä on niiden etymologinen tausta. Luvussa 3 tutkin, miten näitä sanoja taivutetaan toisaalta suomen, toisaalta romanikielen mukaan. Luvussa 4 tarkastelen yksittäisiä sanoja pidempiä romanikielisiä jaksoja ja luvussa 5 johtamista ja yhdyssanojen muodostusta. Luvussa 6 suhteutan havaintojani siihen, mitä pararomaneista tiedetään, ja pohdin, voiko Suomen romanien verkkokeskustelujen kieltä luonnehtia pararomaniksi. Artikkelin lopuksi luvussa 7 kokoan keskeiset havaintoni yhteen.

\section{Romanikielinen leksikko suomenkielisissä lauseissa}

Tässä luvussa tarkastelen sitä, miten romanikieliset lekseemit jakautuvat eri sanaluokkiin (2.1) ja millainen on niiden etymologinen tausta (2.2). Päähuomio on määrällisessä tarkastelussa.

\subsection{Lekseemit, niiden käyttöesiintymät ja taivutusmuodot}

Romanikieltä sisältävien lekseemien edustumat aineistossa perustuvat yhteensä 188:aan romanikielen lekseemiin. Tässä alaluvussa esittelen nämä lekseemit ja niitä edustavien saneiden määrät. Tarkastelun avulla osoitan, mitä romanikielistä sanastoa verkko-

6. Palstan esittely on suomenkielinen, ja suurin osa viesteistä on suomeksi. 
keskustelussa käytetään ja missä määrin sillä korvataan vastaavia suomenkielisiä sanoja. Kaikkiaan romanikielisten sanojen esiintymiä on suomenkielisissä lauseissa 6394 . Kokonaan romanikielisten viestien leksikko on myös suppea mutta laajempi kuin se romanikielinen sanasto, jota käytetään niissä viesteissä, joissa matriisikielenä on suomi. Suomenkielisten viestien romanikieliset elementit ovat kärjistetysti ilmaisten miltei aina tiettyihin tilanteisiin liittyviä vakiintuneita sanavalintoja. Kirjoittajien välillä on kuitenkin eroja, ja näitä yksilöllisiä eroja pyrin selvittämään seuraavassa osatutkimuksessani.

Taulukosta 1 näkyvät verkkokeskustelupalstan suomenkielisissä lauseissa vähintään kymmenen kertaa esiintyvät romanikieliset lekseemit aineistossa esiintyvine kirjoitusasuineen ja suomenkielisine käännöksineen. Taulukosta käyvät ilmi myös lekseemien esiintymämäärät ja -ympäristöt. Varsinaisessa suomenkielisessä keskustelussa käytetyn lekseemin esiintymisympäristö on merkitty sanalla lause. Suomenkielisiksi lauseiksi olen määritellyt ne lauseet, jotka noudattavat suomen kielen rakennetta. Jos lekseemi esiintyy luettelossa, jossa mainitaan irrallisia romanikielisiä sanoja tai ilmauksia ja annetaan niille suomenkieliset käännökset, sen esiintymisympäristö on merkitty lyhenteellä luett. Mikäli romanikielinen lekseemi esiintyy sitaatissa, esimerkiksi musiikkiyhtyeen nimessä, sen esiintymisympäristö on merkitty lyhenteellä sit. Kunkin lekseemin kohdalle on merkitty se esiintymisympäristö, joka kuvastaa sanan aktiivisinta käyttöä. Aktiivisuus tarkoittaa tässä sitä, että esimerkiksi kaksikielisessä sanaluettelossa esiintyvä käyttö kertoo enemmän kielitaidosta kuin pelkkä sitaatti ilman suomennosta, koska sanaluettelo tarjoaa sanoille käännökset. Taulukossa 1 on siis vain vähintään kymmenen kertaa esiintyvät romanikieliset lekseemit; sen sijaan taulukoihin 3 ja 4, jotka ovat verkkolehden liitteenä, on koottu kaikki aineiston lekseemit aakkosjärjestyksessä.

\section{Taulukko 1.}

Aineistossa vähintään kymmenen kertaa esiintyvät lekseemit. Lekseemit on esitetty sanakirjan hakumuodossa; nomineista on ilmoitettu yksikön nominatiivimuoto ja verbeistä Ainfinitiivi.

\begin{tabular}{l|l|r|l}
$\begin{array}{l}\text { Lekseemi ja sen suomen- } \\
\text { kielinen merkitys }\end{array}$ & Kirjoitusasu & Frekvenssi & $\begin{array}{l}\text { Esiintymis- } \\
\text { ympäristö }\end{array}$ \\
\hline kaalo' 'romani' & kaalo, kaale, kaalee, kale & 3259 & lause \\
\hline $\begin{array}{l}\text { gaajo 'ei-romani' } \\
\text { gaajo, gaje, kaajo, kaajee, } \\
\text { kaavo }\end{array}$ & 1388 & lause \\
\hline romano 'romani-' & romano & 206 & lause \\
\hline rakli 'ei-romanityttö' & rakli, räkli & 175 & lause \\
\hline džuuli'(romani)nainen' & juuli & 138 & lause \\
\hline $\begin{array}{l}\text { hai (interjektio/terveh- } \\
\text { dys) }\end{array}$ & hai & 113 & lause \\
\hline raklo 'ei-romanipoika' & raklo & 89 & lause \\
\hline $\begin{array}{l}\text { gaaji 'ei-romaninainen' } \\
\text { kaaji, kääji }\end{array}$ & 62 & lause \\
\hline
\end{tabular}

7. Analysoinnissa on erotettu romanikielen substantiivi kaalo 'romani' romanikielen adjektiivista kaalo 'musta'. 
SALO Romanikielinen ja romanikieleen pohjautuva aines verkkokeskustelussa

\begin{tabular}{|c|c|c|c|}
\hline hortto 'aito, oikea' & hortto & 41 & lause \\
\hline džeero 'raukka' & jeero & 49 & lause \\
\hline louvo 'raha' & louvo & 50 & lause \\
\hline džeeno 'mies' & jeeno & 46 & lause \\
\hline bakro 'lammas' & bakro & 30 & lause \\
\hline $\begin{array}{l}\text { baliȟn-i (F) / -o (M) } \\
\text { 'sika' }\end{array}$ & balihni (F), balihno $(\mathrm{M})$ & 28 & lause \\
\hline ȟohav-'valehdella' & hoha- & 29 & lause \\
\hline tšoor- 'varastaa' & soor-, tsoor- & 25 & lause \\
\hline jolkav- 'varastaa' & jolka- & 19 & lause \\
\hline hava (interjektio) & $\begin{array}{l}\text { havaa, havaaa, havaaaaa, } \\
\text { hawaaaaaa }\end{array}$ & 19 & lause \\
\hline petško 'poliisi' & petsko & 18 & lause \\
\hline tšiȟko 'hyvä' & sihko, tsihko & 17 & lause \\
\hline $\begin{array}{l}\text { dinal }-i(\mathrm{~F}) /-o(\mathrm{M}) \\
\text { 'hullu' }\end{array}$ & tinali $(\mathrm{F})$, tinalo $(\mathrm{M})$ & 50 & lause \\
\hline miritš 'helmi' & mirits & 16 & sit. \\
\hline tširikli 'lintu' & tsirikli & 16 & lause \\
\hline diives 'päivä' & diives, tiives & 14 & lause, luett. \\
\hline freidiba 'rauha' & freidiba & 14 & lause \\
\hline koon 'joka' & koon & 14 & luett. \\
\hline min $\check{h}$ 'emätin' & minhu & 14 & lause \\
\hline phurano 'vanha' & phurano & 11 & lause \\
\hline $\begin{array}{l}\text { rankan-i (F) / -o (M) } \\
\text { 'kaunis' }\end{array}$ & rankani $(\mathrm{F})$, rankano $(\mathrm{M})$ & 11 & lause \\
\hline boodos 'sanoma' & boodos & 10 & lause \\
\hline ȟlengav- 'heittää' & lenga- & 10 & lause \\
\hline kardiini 'kivääri' & kartiini, kartiikni & 10 & lause \\
\hline me'minä' & me & 10 & lause \\
\hline
\end{tabular}

Keskusteluaineistossa käytetyimmät romanikieleen pohjautuvat lekseemit ilmaisevat henkilön etnistä alkuperää akselilla romani - muu kuin romani. Näitä sananmuotoja on 5428 kaikkiaan 6394 romanikielisestä sanaesiintymästä. Selvästi yleisimmät etnistä taustaa ilmaisevat lekseemit ovat kaalo 'romani' ja gaajo 'ei-romani'. Sekä etnistä taustaa että sukupuolta ilmaisevat džuuli 'romaninainen', rakli 'ei-romanityttö', raklo 'ei-romanipoika', gaaji 'ei-romaninainen' ja džeeno 'romanimies'. Suomenkielisissä lauseissa käytetään myös sanoja siivi (feminiini) ja siiva (monikko) 'ei-romani' (3 es.) sekä sessi 'emäntä, ei-romaninainen' (1 es.). Etnistä alkuperää ilmaisevista sanoista on tehty myös useita suomen kielen mukaisia yhdyssanoja ja johdoksia (esim. kaaleennainen, raklottelu). Kymmeniä esiintymiä on lisäksi lekseemeistä džeero 'raukka', bakro 'lammas' ja baliȟno 'sika', joita käytetään yleensä affektisesti ja adjektiivinomaisesti. 
Samoin interjektiot hai ja hava ( hawa), joihin liittyy etnisyyttä ilmaisevaa latausta, esiintyvät melko usein. Näistä hava on leimallisemmin romanien itsensä käyttämä huudahdus, vaikka sen etymologiasta ei ole varmuutta, ${ }^{8}$ kun taas hai esiintyy useimmiten kommenteissa, jotka vaikuttavat oman arvioni perusteella muiden kuin romanien kirjoittamilta.

Adjektiiveista yleisimpiä ovat romano 'romani/romani-' hortto 'aito, oikea', tšiȟko 'hyvä' ja dinalo 'hullu'. Myös adjektiivia phurano 'vanha' käytetään suomenkielisissä lauseissa yli kymmenen kertaa. Yleisimmistä adjektiiveista etnisyyteen ja romanikulttuuriin viittaavia sanoja ovat romano ja hortto, joilla viitataan aineistossa yleensä aitoon romaniuteen tai oikeaan romanikulttuuriin kuuluviin asioihin. Verbeistä yleisimmät ovat tšoor- 'varastaa', jolkav- 'varastaa', h̆lengav- 'heittää' > lengailla 'taiteilla liikutellen puukkoa' ja h̆oh̆av- 'valehdella'. Näistä lengailla liittyy erityisesti romanikulttuuriin. Useimmista lekseemeistä on suomenkielisissä lauseissa vain yksi tai muutama esiintymä. Lekseemeistä hortto 'aito, oikea' ja boodos 'viesti' esiintyvät usein erisnimien osana (musiikkiyhtyeiden nimissä Hortto Kaalo ja Freidiba Boodos).

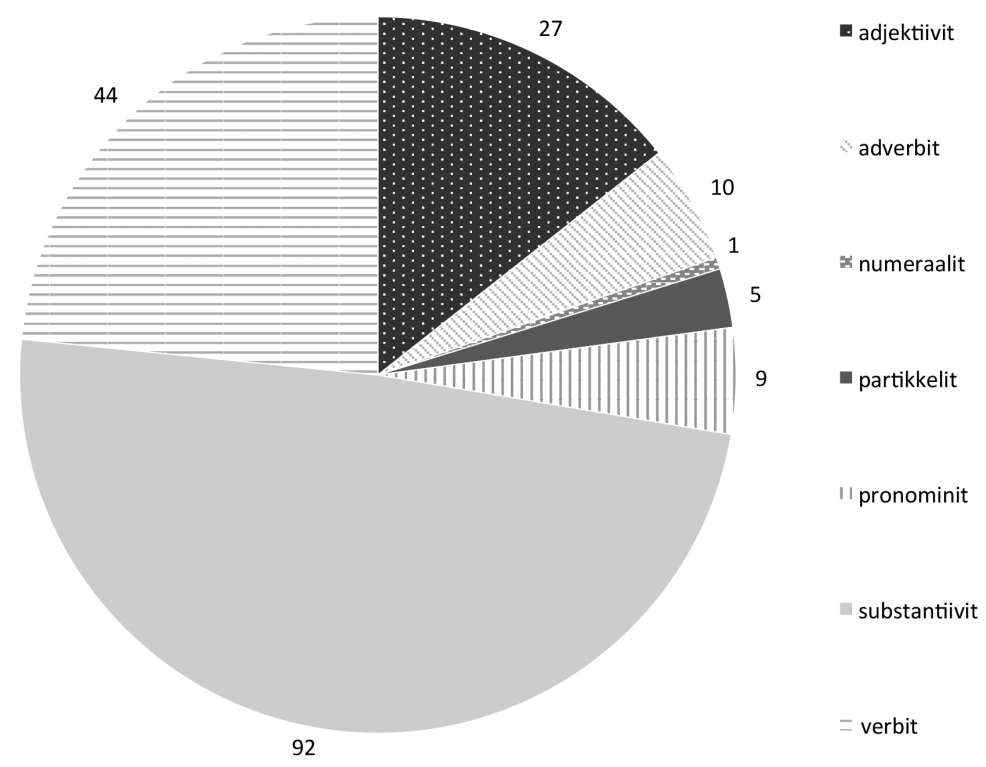

Kuvio 1.

Romaanikieliset lekseemit sanaluokittain $(\mathrm{N}=188)$.

Kuvio 1 esittää lekseemien jakautumisen sanaluokkiin aineiston suomenkielisissä lauseissa. Olen luokitellut aineiston romanikielisiä elementtejä sisältävät lekseemit sanaluokittain. Sanaluokkajaossa selvästi suurin ryhmä ovat substantiivit (49 \%). ${ }^{9}$

8. Valtosen etymologisessa sanakirjassa (1972) ei mainita sanaa, mutta se pohjautuu mahdollisesti turkin kieleen.

9. Sanan džeero esiintymiä on sisällytetty sekä substantiivien että adjektiivien joukkoon, koska sillä 
Kielikontaktien tutkimuksessa on havaittu substantiivien lainautuvan helpommin kuin verbien (esim. Granqvist 2013a: 120-121; Schmidt \& de Bot 2004: 215). Romanikieleen pohjautuvia verbejäkin on kuitenkin lainautunut Suomen romanien suomeen, ja niitä käytetään myös verkkokeskustelun suomenkielisissä lauseissa. Erilaisia verbi(23\%) ja adjektiivilekseemeitä (14\%) esiintyy kaikkiaan melko paljon, kun taas erilaisten pronomini- (5\%), adverbi- (5\%) ja partikkelilekseemien (3\%) yhteenlaskettu määrä on lähes sama kuin adjektiivien. Numeraaleja on vain yksi (1\%), ja sekin esiintyy sanaluettelossa. ${ }^{10}$ Useimpien kymmentä suurempien numeraalien muodostaminen on romanikielessä yksinkertaistunut, ja niiden käyttö romanikielellä on vähentänyt. Tämä on havaittu monissa tutkimuksissa (Granqvist 2007: 334; Kovanen 2010: 33-35, 2013: 122, 126).

\subsection{Lekseemien etymologia}

Seuraavaksi esittelen aineistossa esiintyvien romanikielisten lekseemien (yht. 188) alkuperää. Lähteenä olen käyttänyt Pertti Valtosen etymologista sanakirjaa (1972). Valtonen on esittänyt joidenkin sanojen alkuperäksi useita eri sanoja, jotka voivat edustaa eri kieliä. Jokainen näistä mahdollisista lähtösanoista on huomioitu laskelmissa.

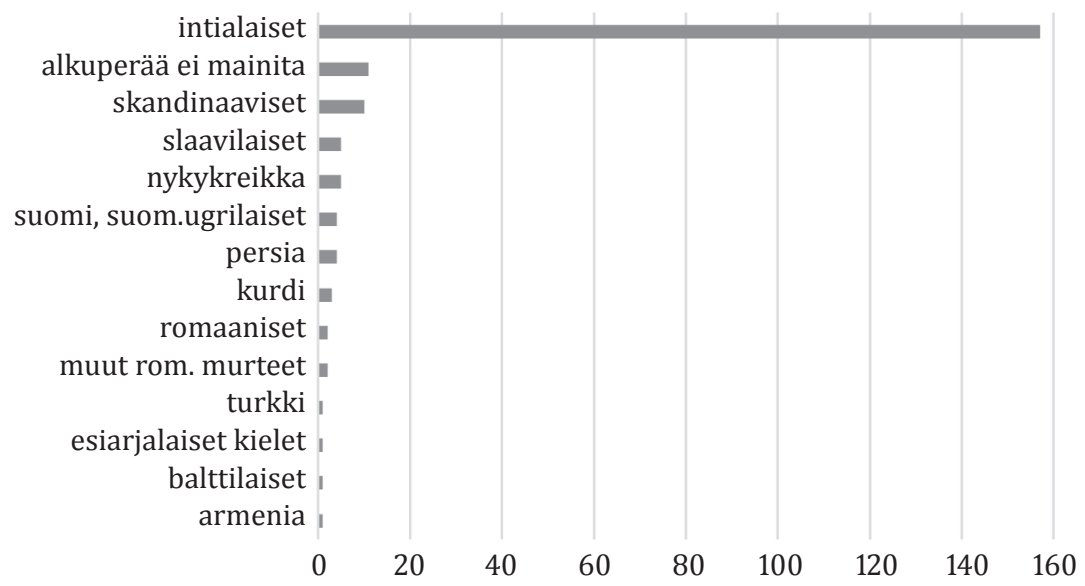

Kuvio 2.

Romanikielisten lekseemien etymologiset alkuperät.

Kuviosta 2 ilmenee, että verkkokeskustelussa esiintyvistä lekseemeistä valtaosa on romanikielen vanhaa intialaisperäistä sanastoa. Verkkokeskustelussa suositaan siis eniten sellaisia romanikielen sanoja, joilla on indoarjalainen tausta. Kuviossa viittaan näi-

on aineistossani kummankinlaista käyttöä.

10. Aineiston romanikielisissä lauseissa esiintyy useita romanikielen numeraaleja: sekä yksinkertaisesti muodostettavia, kuten heel (< eel) 'sata' ja deh 'kymmenen', että kymmenlukujen ilmaisuja, kuten panghvardeh-ta-triinjako 'viisikymmentäkolmevuotias', eftavardehho iek 'seitsemänkymmentäyksi' ja stavardehho'seitsemänkymmentä'. 
hin sanoihin sanalla intialaiset, joka kertoo romanikielisten sanojen maantieteellisestä alkukodista. Skandoromanin sanastossa esiintyy samanlainen ilmiö: Eztlerin (1944: 240) mukaan skandoromanin ytimen muodostaa indoarjalainen leksikko. Kuviossa on eroteltu lekseemien skandinaavinen alkuperä (nykynorja, nykyruotsi ja nykytanska) muista germaanisista kielistä sen vuoksi, että Suomen romanikielen leksikossa on huomattava määrä nimenomaan ruotsista saatuja lainoja. Valtonen (1972) on merkinnyt nämä maininnalla uusi laina. Hän mainitsee niiden lisääntyvän jatkuvasti Suomen romanikielessä ja olevan käytössä sekä Itä- että Länsi-Suomen romaneilla (mts. 6).

Yhteenvetona tästä luvusta voidaan todeta, että suurin osa verkkokeskustelussa käytetyistä romanikieleen pohjautuvista lekseemeistä on vanhaa indoarjalaista perua ja sanaluokaltaan yleisimmin substantiiveja, jotka tyypillisesti ilmaisevat etnistä ja kulttuurista eroa romanin ja muun kuin romanin välillä. Seuraavaksi tarkastelen romanikielisen sanaston taivutusta.

\section{Romanikielisten ja romanikieleen pohjautuvien sanojen taivutus}

Tässä luvussa käsittelen romanikielisten ja romanikieleen pohjautuvien sanojen taivutusta suomenkielisessä lauseyhteydessä. Taivutuksen tarkastelu on tarpeen sen selvittämiseksi, missä määrin romanikielen kieliopin mukaisten muotojen käyttö on säilynyt vai onko kyse vain irrallisten sanojen tuntemuksesta. Samalla käy ilmi, kuinka paljon valtakielellä eli suomella on ollut vaikutusta morfologiaan.

\subsection{Suomen kieliopin mukaan taivutetut sanat}

Romanikieliset sanat taivutetaan yleensä verkkokeskustelun suomenkielisissä lauseissa suomen kieliopin mukaisesti. Esimerkin 1a muoto prehta-va-a on muodostettu romanin verbistä presav- > prehta- 'maksaa' suomen partisiippitaivutuksen mukaisesti ja taivutettu partitiivissa (esim. maksa-va-a). Romanien suomessa yleinen verbi lansata pohjautuu romanikielen substantiiviin lans 'häpeä, kunnioituksen osoittaminen' ja verbiin lansav- 'hävetä, osoittaa kunnioitusta', mutta se on mukautettu suomen kielioppiin ja edustaa supistumaverbejä. Esimerkkilauseessa $1 \mathrm{~b}$ kirjoittaja on merkinnyt infinitiivimuodon lansa-ta perään $a$ :n, mikä on todennäköisesti lyöntivirhe.

(1) a. - - ei katetuissa ostoskeskuksissa käveltäessä tarvita näin prehta-va-a lämpöeristettä

maksavaa-PTCP-PAR

'ei katetuissa ostoskeskuksissa käveltäessä tarvita näin (paljon) maksavaa lämpöeristettä

b. lansa-taa saa taas näiden otsikoiden takia

hävetä-INF

'hävetä saa taas näiden otsikoiden takia' 
Myös romanien suomeen vakiintuneet substantiivit, kuten siiva 'ei-romanit', kaalo 'romani' ja kaajo/kaaje(e) 'ei-romani', taivutetaan tyypillisesti suomen mukaisesti. Niissä esiintyy kuitenkin usein kaksi monikon tunnusta (double plural, ks. esim. Nordqvist 2017): romanikielen monikkomuodon perään on lisätty suomen monikon tunnus, kuten kaal-ee-t ja kaaj-ee-t esimerkissä 2a. Havaintojeni mukaan useat keskustelijat käyttävät romanikielen monikkomuotoja kaal-e ja kaaj-e (tai kaal-ee, kaaj-ee) yksikkömuotoina suomenkielisissä lauseissa. Esimerkin $2 \mathrm{~b}$ taivutuksen voi tulkita kahdella eri tavalla. Romanikieleen perustuvat verbinmuodot bikna-a 'myyvät, myy' (< biknav- 'myydä) ja tseera-a 'tekevät, tekee' ( $<$ tšeer- 'tehdä) on taivutettu esimerkissä joko romanikielen yksikön 1. persoonassa tai suomen yksikön 3. persoonassa monikon 3. persoonan sijasta. Ensin mainittua ilmiötä esiintyy nykyään Suomen romanikielessä, ja jälkimmäinen on puolestaan suomen kielen vaikutusta. Suomen puhekielessähän on yleistä, että monikollisen 3. persoonan subjektin yhteydessä verbinmuoto on yksiköllinen (ISK $2004 \S 107$ ). Glosseihin olen valinnut suomen mukaisen taivutuksen. Esimerkissä $2 \mathrm{c}$ verbi hoha-ta

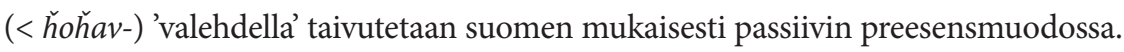
(2) a. - - on aivan yhdentekevää mitä ajattelee kaal-ee-t tai kaaj-ee-t. romani-PL-PL ei-romani-PL-PL ' - - on aivan yhdentekevää mitä ajattelee romanit tai ei-romanit.'

b. jos aikuiset kaal-ee-t bikna-a ni mitä ne nuoremmat

romani-PL-PL myydä-PRS.3SG

sitten tseer-aa kysyn vaan.

tehdä-PRS.3SG

c. kun näyttää siltä että jotkut uskovat kaiken mitä täällä hoha-taan

valehdella-PAss. 4

Verbintaivutuksessa suomen kielen taivutusaines tai johdin liitetään yleensä suoraan romanikieliseen vartaloon kuten esimerkissä $3 a$. Esimerkit $3 \mathrm{~b}-\mathrm{d}$ havainnollistavat nominien taivutusta.

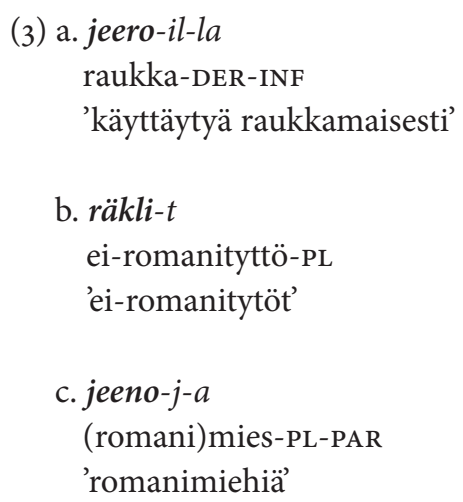




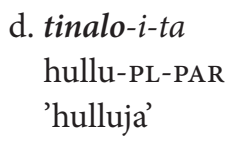

\subsection{Romanikielen mukaan taivutetut sanat}

Suomenkielisissä lauseissa esiintyy myös sellaisia romanikielen sanoja, jotka on taivutettu romanin mallin mukaan. Esimerkissä 4 kirjoittaja kuvailee käytössä olevaa sekakielen kaltaista kielimuotoa, jossa pyritään taivuttamaan romanikielisiä sanoja romanikielen mukaan. Pronomini man-ge-lle 'minulle' on taivutettu romanikielen kieliopin mukaan datiivissa (-ge), mutta siihen on lisätty myös suomen allatiivin taivutuspääte. ${ }^{11}$ Romanikielen pronominien taivutuksessa on nykyään ylipäätään paljon vaihtelua. Datiivimuoto man-ge saattaa korvata tässä nominatiivimuodon me 'minä. Kirjoittajan kuvailemassa kielimuodossa käytetään romanikielen yksikön 1 .

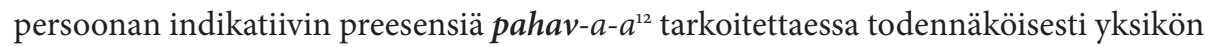
2. persoonan imperatiivimuotoa. Verbistä bah̆av- pahav- 'soittaa' yksikön 2. persoonan imperatiivimuoto kuuluu suomen romanikielessä paha bah̆a 'soita'. Verbintaivutuksen persoonapäätteet ovat yhtenäistyneet joissakin yksilömurteissa siten, että yksikön 2. persoonan (usein myös monikon persoonamuotojen) persoonapäätteen tilalla käytetään yksikön 1. tai 3. persoonan muotoa.

(4) Erilaisuuden pitäis olla rikkaus tässäkin asiassa. Luulen että ihminen joka osaa kaal-ee-n kieltä niin että pystyy sillä kommunikoimaan jollakin tasolla romani-PL-GEN

(enkä tarkoita nyt mitään tyyliin "Hei pahav-a
soittaa-P

man-ge-lle

minä.OBL-DAT-ALL

niin ymmärtävät varmasti myös tätä nykyajan siansaksaa vai miksikä te nyt sitä täällä kutsuittekaan. Ja jollakin tasolla tätä nykyajan siansaksa-kaal-ee-nkieltä osaavat varmaan kykenevät ymmärtämään sitä aitoa, vanhaa kaal-ee-n kieltä.

' - - (enkä tarkoita nyt mitään tyyliin "Hei, soitat minulle sit illalla, ko oot lähtenyt pois sieltä talosta") niin ymmärtävät varmasti myös - - '

11. Suomen romanikielen persoonapronominin datiivi muodostuu persoonapronominin obliikvimuodosta ja datiivin tunnuksesta -ke (SG) / -ge (PL). Suomenkielisessä lauseessa romanikielen datiivimuotoon on lisätty suomen allatiivipääte. Datiivimuoto man-ge esiintyy romanikielisissä lauseissa enimmäkseen konteksteissa, joissa nimenomaan datiivi on odotuksenmukainen sija. Siitä päätellen tässäkin sija on todennäköisesti ymmärretty datiiviksi. Sen perään on siis liitetty suomenkielinen taivutusmuoto, jolloin sama kieliopillinen funktio on merkitty kahteen kertaan.

12. Romanikielen verbi pahav- + 1. persoonan preesensin tunnus $a+$ indikatiivin tunnus $-a$. 
Myös seuraavissa esimerkeissä romanikielinen sana taivutetaan romanin kieliopin mukaisesti. Esimerkit $5 \mathrm{a}-\mathrm{c}$ havainnollistavat substantiivien taivutusta. Esimerkissä $5 \mathrm{a}$ esiintyy genetiivimuoto paholaista merkitsevästä sanasta. Esimerkin $5 \mathrm{~b}$ suomenkielisessä lauseessa käytetään romanikielen sanan haapen 'ruoka' partitiivimuotoa, joka on nominatiivin kaltainen. Esimerkissä $5 \mathrm{c}$ yksi romanikieleen pohjautuvista sanoista taivutetaan romanikielen mukaan (plurale tantum koola 'vaatteet'). Muualla aineistossa sanaa taivutetaan myös kaksoismonikkona suomen kielen monikon tunnuksen - $t$ avulla: koola-t.

(5) a. Teidän kirkko on beng-es-ko huone.

paholainen-OBL.SG-GEN

'Teidän kirkko on paholaisen huone.'

b. Laps on hoijettu viimeisen päälle hyvin ja puhasta on ja haapen on ollut koko ajan.

' - - puhasta on ja ruokaa on ollut koko ajan.'

c. Te, joilla on kaaj-ee-n valp-i-t,

ei-romani-PL-GEN lapsi-PL-PL ${ }^{13}$

älkää antako niitteen laittaa kaal-ee-n koola.

romani-PL-GEN vaatteet

'Te, joilla on ei-romanin lapset, älkää antako niitteen laittaa romanivaatteita.'

Esimerkeissä $6 \mathrm{a}-\mathrm{c}$ verbejä taivutetaan romanikielen mukaisesti (seer-el-a 'teet', lurr-eh-a 'ryöstät'). Esimerkissä $6 \mathrm{~b}$ esiintyy Suomen romanikielessä nykyään yleinen ilmiö taivuttaa monikon 3. persoonaa yksikön 3. persoonan mukaisesti. Esimerkissä 6c käytetään romanikielen aktiivin partisiippia naht-o, jonka merkitys on 'karkulainen'. Muoto on myös preteritin yksikön 3. persoonan muoto sanasta nah̆h- 'karata'.

(6) a. - - hyvi menee mustalaislapsilla niikö kaaj-ee-t

seer-el-a

ei-romani-PL-PL tehdä-3SG-IND

on poika ollu - -?

' - - hyvin menee mustalaislapsilla, niin kuin ei-romanit tekevät on poika ollu - -

b. Ketä sinäkin lurr-eh-a?

ryöstää-PRS.2SG-IND

'Kenet sinäkin ryöstät?'

13. Muoto valp-i on romanikielen monikon nominatiivi. Jotkut Suomen romaneista käyttävät muotoa valpi (< valpos) yksiköllisessä merkityksessä 'lapsi'. 


\section{c. Sinä olet jo 'nahto' en estät. Alam mennä minä jään käsii - - karkulainen}

Esimerkin 7a emakkoa merkitsevää sanaa balihni käyttää suomenkielisessä lauseessa vain yksi kirjoittaja. Muilla sana on korvautunut maskuliinimuotoisella sanalla balihno < baliȟno 'sika' myös naisiin viitattaessa. Kumpaakin sanaa käytetään aineistossa ihmisen haukkumasanana. Vastaavasti sana tinali < dinali 'hullu' on feminiinimuoto, jonka sijasta aineistossa käytetään myös maskuliinimuotoa tinalo $<$ dinalo 'hullu' silloinkin, kun keskustelu koskee naispuolista henkilöä. Esimerkki $7 \mathrm{~b}$ puolestaan ilmentää adjektiivin taivutusta romanikielen monikkomuodossa (tern-e 'nuoret'). Esimerkissä $7 \mathrm{c}$ kirjoittaja käyttää romanikielen adverbia kokares 'yksin'.

(7) a. Kehtaat tuommosta vielä puhua, häpeä balihn-i!

sika-F (emakko)

$$
\begin{aligned}
& \text { b. - - kuin se että tern-e } \\
& \text { nuori-PL } \begin{array}{l}
\text { kaal-e-i-ta } \\
\text { romani-PL-PL-PAR }
\end{array} \\
& \text { ei laiteta ylimpään kerrokseen jos alhaalla asuu purano-j-a } \\
& \text { vanha-PL-PAR }
\end{aligned}
$$

kaal-e-i-ta.

romani-PL-PL-PAR

'- - kuin se, että nuoria romaneita ei laiteta ylimpään kerrokseen, jos alhaalla asuu vanhoja romaneita.'

c. Minkä ikäisijä muuten oot ja ootkos kokares jeeno.

yksin mies

Muutamia yksittäisiä romanikielen sanoja käytetään useamman kerran kuvainnollisesti. Yksi tällaisista sanoista on adverbi fallo (< phallo), joka merkitsee 'kiinni' (8ab). Sitä käytetään merkityksessä 'vankilaan, vankilassa'.

(8) a. syyllinen/syylliset ei saa mitään ja uhrit ovat fallo.

b. ja ne vievät siut 'fallo'.

Kun kyse on romanikielisistä tai romanikieleen pohjaavista sanoista, romanikieliset taivutusmuodot ovat aineiston suomenkielisissä lauseissa harvinaisempia kuin suomenkieliset. Niiden käyttö on yksilöllistä, ja useita niistä löytyy vain yhdeltä kirjoittajalta. Taulukko 2 esittää suomenkielisten lauseiden yhden tai kahden sanan pituisissa jaksoissa ${ }^{14}$ esiintyvät romanikielen mukaan taivutetut sanat sekä sanat, joissa on

14. Mukana eivät ole tervehdykset eivätkä kollokaatiot. 
niin romanikielen kuin suomen kieliopin mukaista taivutusta. Taulukkoon on merkitty myös sanaluokat ja taivutusmuodot.

Taulukko 2.

Suomenkielisissä lauseissa käytetyt romanikieliset taivutusmuodot.

\begin{tabular}{|c|c|c|}
\hline Sana & Esiintymämäärä & Sanaluokka ja taivutusmuoto \\
\hline balihn-i & 1 & substantiivi-F \\
\hline beng-es-ko & 1 & substantiivi-OBL-GEN ${ }^{15}$ \\
\hline butti-ja-ko & 1 & substantiivi-OBL-GEN \\
\hline fallo/phallo & 7 & adverbi \\
\hline haapen & 1 & substantiivi.PAR \\
\hline hyövy-n-äs & 1 & verbi-3PL-COND \\
\hline hyövyv-eh-a & 1 & verbi-2SG-IND \\
\hline$i k k a v-a-a$ & 1 & verbi-1SG-IND \\
\hline kaml-i & 1 & adjektiivi-F \\
\hline kokares & 1 & adverbi \\
\hline koola & 1 & substantiivi.PL \\
\hline lurr-eh-a & 1 & verbi-2SG-IND \\
\hline maaro & 1 & substantiivi.PAR \\
\hline man-ge & 2 & pronomini-DAT \\
\hline naht-o & 1 & adjektiivi-PTCP \\
\hline rankanes & 1 & adverbi \\
\hline rankan-i & 1 & adjektiivi-F \\
\hline seer-el-a & 1 & verbi-3SG-IND \\
\hline$t-e l-a$ & 1 & verbi-3SG-IND \\
\hline tern-e & 1 & adjektiivi-PL \\
\hline tinal-i & 5 & adjektiivi-F \\
\hline
\end{tabular}

Kun tarkastellaan aineistosta sellaisia jaksoja, joissa romanikieltä esiintyy vain yksi tai kaksi sanaa, voidaan havaita, että niissä romanikielistä taivutusta esiintyy 21:ssä eri lekseemissä. Nämä lekseemit edustavat viittä sanaluokkaa (substantiivi, adjektiivi, adverbi, verbi ja pronomini) ja taipuvat nominien osalta kolmessa sijamuodossa (nominatiivi, genetiivi ja datiivi) sekä verbien osalta kahdessa tapaluokassa (indikatiivi ja konditionaali) ja neljässä eri persoonassa (yks. 1., 2. ja 3. pers. sekä mon. 3. pers.). Feminiinisukuisen substantiivin balihni < baliȟni'emakko' käyttö on myös osaltaan esimerkki romanikielen kieliopillisen suvun ymmärtämisestä. Romanikielistä taivutusta käytetään sijan, luvun, suvun ja moduksen ilmaisemiseen siis suomenkielisessäkin

15. Suomen romanikielen genetiivimuoto muodostetaan sanan vartalosta, obliikvin tunnuksesta -es-/-ja- ( $\mathrm{SG}$ ) / -en- (PL) sekä genetiivin tunnuksesta -ko (SG) / -go (PL): beng-es-ko, butti-ja-ko. Romanikielessä obliikvi on elollisen suoran objektin sija. 
keskustelussa. Tämä osoittaa romanikielistä taivutusta käyttävien keskustelijoiden tuntevan romanikielen kielioppia.

Tässä luvussa esitellyt tulokset näin ollen osoittavat, että Suomen romanien suomenkielisessä keskustelussa esiintyy romanikieleen pohjautuvan sanaston lisäksi useita romanikielen kieliopillisia rakenteita, vaikka onkin tyypillisempää, että romanikielistä sanastoa taivutetaan suomen morfologian mukaisesti. Seuraavaksi tarkastelen yksittäisiä sanoja pidempiä romanikielisiä jaksoja suomenkielisessä keskustelukontekstissa.

\section{Pitemmät romanikieliset jaksot suomenkielisissä lauseissa}

Aiemmat tutkimukset osoittavat, että koodinvaihdolla, fraaseilla ja romanikielisillä sanoilla on erityis- ja lisämerkityksiä suomenkielisessä keskustelussa (Granqvist \& Viljanen 2002; Åkerlund 2004; Hedman 2004, 2009; Granqvist 2009; Kovanen 2010, 2013; Salo 2016). Samaa on havaittavissa omassa aineistossani. Jotkin romanikieliset ilmaisut esiintyvät usean eri kirjoittajan suomenkielisissä viesteissä fraaseina eli vakiintuneina sanontoina tai kollokaation tapaan, jolloin kyse on usein yhdessä esiintyvien sanojen kokonaisuudesta. Näitä, kuten muitakin romanikielen aineksia, käytetään tulkintani mukaan etnisen identiteetin ilmaisuun ja keskustelun rajaamiseen romaniyhteisön piiriin. Matras ym. (2007: 34-35) ovat tehneet vastaavan havainnon angloromanista. Angloromanin puhujat osaavat romanikieliset ilmaisut myös valtakielellä (mp.), ja vastaavasti romanikieltä sisältävän suomen käyttäjät osaavat romanikieleen perustuvat ilmaisut myös suomeksi, eli kyse ei ole kielitaidon puutteesta. Tässä luvussa tarkastelen ensin romanikielisiä fraaseja ja muita kahden tai useamman sanan yhteisesiintymiä (alaluku 4.1) ja sen jälkeen pidempiä koodinvaihtojaksoja (alaluku 4.2).

\subsection{Yhteisesiintymät}

Esimerkeissä 9a-c esiintyy romanikielinen jakso, jossa demonstratiivipronomini ja suomen olla-verbiä vastaava verbi on ilmaistu romanikielellä (tauva hin); esimerkin $9 \mathrm{c}$ alussa on lisäksi romanikielinen yksikön 2. persoonan imperatiivimuoto (tik). Esimerkin $9 \mathrm{~d}$ jakso, jossa on romanikielen monikon 2. persoonan imperatiivi (tikken) ja adverbi (kaan), saattaa olla yhtenä fraasina opittu kokonaisuus.

(9) a. Tauva h-in tosi hieno laulu

tämä olla-PRs.3SG

'Tämä on tosi hieno laulu.'

b. Tauvah-in niinku rikitalle kirjotettu lauluu.

tämä olla-PRS.3SG

'Tämä on niin kuin Rikitalle kirjoitettu laulu.'

c. tik mikä ihme tauva h-in? mikä on ongelma kaaj-ee-n

katso.2SG.IMP tämä olla-PRS.3SG ei-romani-PL-GEN 
lapsella ko tulee tänne kirjottelemaan tuommosija pitäs vanhempijen pittää parempaa huolta lapsestaan - -

'Katso mikä ihme tämä on? mikä on ongelma - -'

d. tikk-en kaan no ei oo kauaakaa aikaa ko sanoit että oot - -

katsoa-2PL.IMP nyt

'Katsokaa nyt, no ei oo kauaakaa aikaa ko sanoit, että oot - -'

Verkkokeskustelun viestit päättyvät välillä romanikieliseen toivotukseen, kuten seuraavissa esimerkeissä (10a-d). Yleisen toivotuksen 'ole/olkaa Jumalan kanssa, Jumalan haltuun, näkemiin' alkuosa on yksikön (esimerkissä 1oc monikon) imperatiivi verbistä $a a \breve{h}$ - 'olla' ja jälkimmäinen sana yleensä instrumentaali sanasta Deevel 'Jumala.' Instrumentaali esiintyy aineistossa muodoissa Deevel-sa (yks.), Deul-eha (yks.), Deevel-es-sa (yks.) ja Deul-e-na (mon.). Lisäksi esiintyy obliikvimuoto ${ }^{16}$ Deuvel-es.

(10) a. - - on tietokone muisti, työn puolesta piti olla. Aah

olla.2SG.IMP

deul-e-ha.

Jumala-OBL.SG-INS

b. - - vähän niin kuin parempaa. Laita jokin linkki. Aah

olla.2SG.IMP

Deul-e-na.

Jumala-OBL.PL-ABL

c. - - muihin ihmisiin - - Toivon sinulle kaikkea hyvää -aahh-en

olla-2PL

deevel-es-sa.

Jumala-OBL.SG-INs

d. taitaapi olla minun siskoni stadista semmonen komija lady ketä saa - - nauraaaa että sihko diives vaan sysse;)

hyvä päivä

'- - nauraa että hyvää päivää vaan - -'

Esimerkkilauseet muistuttavat toisiaan, ja kyseessä on todennäköisesti yhtenä kokonaisuutena opittu toivotus. Niissä esiintyy kuitenkin yksilöllisiä eroja instrumentaalin muodostuksessa. Myös romanikielisiä tervehdyksiä, kuten sihko tiives 'hyvää päivää ja tsihko Juula/kvella/niijal/rat 'hyvää joulua/iltaa/kesää/yötä, esiintyy, jotkin niistä

16. Romanikielessä obliikvi on siis objektin sija; siihen liitetään myös nominien sijamuodot. 
c. - - ja viellä on valitettavaa sekin että kun huusa ei anna kauppa

kaal-e-i-n naisille ei

romani-PL-PL-GEN

tsohha-a niin ei oo kaal-e-i-n naisiakaan kohta - -

hame-PAR romani-PL-PL-GEN

ei pitäis olla noin ylimielinen kun sinullakaan ei oo kohta mekkoo

kun huusa na t-el-a.

kauppa NEG antaa-PRS.3SG-IND

' - -että kun kauppa ('sosiaalivirasto'?) ei anna romaninaisille hametta niin ei ole romaninaisiakaan kohta - - kun sinullakaan ei oo kohta mekkoo kun kauppa ('sosiaalivirasto'?) ei anna.'

d. sillä olen elälyt sen ajan kun tsaar-e kaal-e kulkivat ja

kaikki-PL romani-PL
kaml-e
tsiiv-en-na
tsaar-e koola,
pyytää.PRT-2/3PL
ei-romani-PL.OBL-ABL kaikki-PL vaatteet
ja ei ollut mahdollista esittää väri alanlyysiä, että todellakin pukivat sitä
päällensä tsoo l-iin-e tsiiv-en-na
jota saada-PRT-2/3PL ei-romani-PL.OBL-ABL
- - en viitsi kaikkia suomentaa kun minua inhottaa kun tsekkarit aina on joka asiaaa vääristelemässä kaa-le-i-n elämästä ja pilkkaamassa,
romani-PL-PL-GEN

ett olisi paljon muita asioita mitä meidän pitäisi oikeassa hengessä täällä puida.

'Sillä olen elänyt sen ajan, kun kaikki romanit kulkivat ja saivat ystävällisiltä ei-romaneilta kaikki vaatteet, ja ei ollut mahdollista esittää värianalyysiä, että todellakin pukivat sitä päällensä, jota saivat ei-romaneilta - - en viitsi kaikkea suomentaa, kun minua inhottaa, kun tsekkarit aina on joka asiaa vääristelemässä romanien elämästä - -’

Esimerkeissä 12a-d romanikieltä käytetään sellaisessa lauseen osassa, jonka merkitystä ei tarvitsisi piilottaa: tola hin jeele 'he ovat menneet', taala hin saare 'ne/he ovat 
kaikki' sekä maaro hin buut 'leipää on paljon'. Romanikielisten jaksojen käytöllä kirjoittajan voi tulkita manifestoivan omaa ja esimerkissä 12a myös puheena olevien henkilöiden romani-identiteettiä ja romanikielen taitoa. Jaksot ovat kieliopillisesti virheettömiä. Esimerkkien 12a ja 12b koodinvaihto-osa sisältää subjektin ja predikaatin, joiden tulkitsemisen avuksi on ilmaistu lisätietoa suomeksi. Esimerkissä 12c koodinvaihto on kokonainen lause, joka liittyy kuitenkin laajempaan suomenkieliseen kuvaukseen. Näissä esimerkkilauseissa esiintyy koodinvaihtoa romanikielelle, josta palataan takaisin suomen kieleen. Esimerkissä 12d verbi hajuv- 'ymmärtää' on taivutettu romanikielen mukaan (yksikön 1. persoonassa tarkoitettaessa yksikön 2. persoonaa) ja siihen on liitetty lisäksi suomenkieliset liitepartikkelit $-k o+-s>-k s$. Muodon merkitys on 'ymmärrätkös'. Yksikön 2. persoonan persoonapronomini ilmaistaan romanikielen obliikvisijassa. Esimerkissä 12e lainaus mui fallo on lainausta toisen kirjoittajan viestistä. Romanikielisessä osassa on substantiivi ja adverbi, ja se on muodoltaan kokonainen lause.

(12) a. Ei ne ole kavonneet. Tola $h$-in j-eel-e suomenkielen kursseille. ne olla-PRS.3SG/PL mennä-PRT-2/3PL

' - - Ne/he ovat menneet suomen kielen kursseille.'

$\begin{array}{rll}\text { b. Niinhän taala } & h \text {-in } & \text { saare ja unohtavat senmitä } \\ \text { nämä } & \text { olla-PRS.3SG/PL kaikki }\end{array}$

oikeesti ovat ja mihin --

'Niinhän nämä ovat kaikki ja unohtavat - -'

c. - - kerjäillä pakkasella yösijaa, autot on alla maaro $h$-in

leipä olla-PRS.3SG/PL

buut, ollaan siirrytty mailta kaupunkeihin ja--

paljon

'- - autot on alla, leipää on paljon, ollaan siirrytty maalta - -'

d. En ymmärrä hajuv-a-ks tuut mihi tämä maalima - ymmärtää-PRS.1SG-CLI sinä.OBL

'En ymmärrä, ymmärrätkös sinä mihin tämä maailma - -'

e. Vai mui fallo tsot tsot pikkusen pitää aatella mitä puhuu.

'Vai suu kiinni, tsot tsot pikkusen pitää aatella mitä puhuu.'

Tiivistäen voidaan sanoa, että suomenkielisissä viesteissä käytetään paitsi muodoltaan vakiintuneita toivotuksia ja parin romanikielisen sanan yhdistelmiä myös vähemmän vakiintuneita sanaliittoja ja pitempiä jaksoja. Pitemmissä romanikielisissä jak- 
soissa esiintyy virheetöntä romanikielen kielioppia mutta myös suomen kielen mukaisuuksia. Suomen vaikutusta voi havaita muun muassa persoonapäätteiden käytössä ja maskuliinisuvun käyttämisessä myös naisista puhuttaessa (ks. Granqvist 2013a: 131-132; Granqvist \& Pirttisaari 2003: 36-37). Taivutuksen yksinkertaistumista ilmenee siinä, että monikon funktiossa käytetään yksikkömuotoa.

\section{Johtaminen ja yhdyssanat}

Tutkimissani verkkokeskusteluissa on myös suomen kielen mukaan muodostettuja johdoksia ja yhdyssanoja, jotka sisältävät sekä suomen kieleen että romanikieleen pohjautuvan osan. Joistakin sanoista on kehitetty suomen kielen mallin mukaisia uudissanoja, kuten verbikantainen substantiivi jeero-il-u 'raukkamainen käytös', jota taivutetaan suomen mukaisesti esimerkiksi jeero-il-u-a-an (<rom. jeero $\sim$ džeero 'raukka'-DER-DER-PAR-SUFF) ja verbi jeero-il-la 'käyttäytyä raukkamaisesti', jota käytetään muodoissa jeero-il-i (jeero džeero 'raukka'-DER-PRT) ja jeero-il-le-n (jeero džeero 'raukka'-DER-INF-INSTR). Esimerkkejä johdoksista ovat myös adjektiivit bakromais-i-a (< rom. bakro 'lammas'-DER-PL-PAR) ja iina-ttava (< rom. iinav-, 'inhota, vihata'-PPTCP). Romanikieleen pohjautuvista substantiiveista on muodostettu myös esimerkiksi verbikantainen tekijännimijohdos kääji-tteli-jö-i-stä (< rom. gaaji, 'eiromaninainen-DER-DER-PL-ELA) sekä teonnimijohdokset raklo-tte-lu-un (< rom. raklo, 'ei-romanipoika-DER-DER-ILL) ja räkli-tte-ly- $t$ (< rom. rakli, 'ei-romanityttö'DER-DER-PL). Verbikantaisia teonnimiä ovat esimerkiksi lenga-i-lu 'taiteilu puukolla' (romanikieleen pohjautuvasta, suomen verbintaivutukseen mukautetusta verbistä lengailla ( $<$ h̆lengav- 'heittää), t-elaa-minen $(<d$ - 'antaa') ja tseeraa-minen $(<t$ šeer'tehdä').

Suomea ja romanikielisiä elementtejä sisältäviä yhdyssanoja on aineistossa runsaasti. Niistä suurimmassa osassa on määriteosana sanan kaalo 'romani' nominatiivimuoto, sen suomen kieliopin mukaan muodostettu genetiivimuoto kaalo- $n$ tai melkein yhtä yleinen genetiivimuoto kaal-ee- $n$. Määriteosana on usein myös kaajo 'eiromani'. Kyseessä ovat kaksi aineistossa yleisimmin esiintyvää romanikielistä lekseemiä. Näistä on muodostettu lukuisia yhdyssanoja, kuten kaalemies, kaalenainen, kaalonpoika, kaalenvaatteet, kaaleenhame, kokokaalo, kaalorealismin, kaajenpojan, virkakaajeillekin, kaajeentyylinen ja kaajenmoisuutta. Esimerkkejä muista romanikielen ja suomen aineksista muodostetuista yhdyssanoista ovat substantiivit jeerolaps (< rom. džeero, 'raukka' + su. lapsi) ja kulttuurifuulaa (< su. kulttuuri + rom. fuul, 'lika, saasta, uloste') sekä adjektiivi tinakahjo (< rom. tinalo, 'hullu'+ su. kahjo). Romanikielen omista aineksista muodostetun yhdyssanan horttokaalo 'aito romani, oikea romani'(joskus myös merkityksessä 'kummankin vanhemman puolelta romani') alkuun on toisinaan lisätty vielä suomenkielinen sanan osa, esimerkiksi täyshorttokaalo. Romanikielisiä aineksia sisältäviä johdoksia ja yhdyssanoja taivutetaan kaikissa keskustelukäytössä tarvittavissa suomen sijamuodoissa. 


\section{Romanikieltä sisältävä suomi verrattuna pararomaneihin}

Edellä olen tarkastellut sitä, millä tavalla romanikieltä käytetään suomenkielisissä verkkokeskusteluissa. Tässä luvussa pohdin, missä määrin tämä käyttö suhteutuu niin sanottuihin pararomaneihin. Romanikielistä ainesta sisältävää suomea voi verrata pararomaneihin siinä mielessä, että siinä on kyse valtaväestön kieleen sisällytettyjen romanikielisten ainesten käytöstä. Pararomanilla nimittäin tarkoitetaan romanikielen tutkimuksessa kielimuotoa, jossa on vain sanastoa romanikielestä, mutta lähes koko rakenne on toisen kielen mukainen (esim. Borezky 1998; Cortiade 1991; Granqvist 2013b). Euroopassa lasketaan puhuttavan yli kymmentä pararomania (Granqvist 2013b: 164). Tällaisia ovat muun muassa Iberian nimimaalla puhuttavat pararomanit caló, calão ja erromint$x e l a$, Ruotsissa ja Norjassa puhuttavat skandoromanit ${ }^{17}$ sekä Brittein saarilla puhuttava angloromani (Romany 'romanikieli', jib 'kieli', poggadi jib 'särkynyt kieli') (mas. 165-175).

Suomen romanien verkkokeskustelu sisältää samanlaisia romanikielisten sanojen käyttötehtäviä, joita tunnetaan pararomaneista (Salo 2016). Esimerkiksi angloromanin ja calón käyttötehtäviä ovat salakieli ja etniseen ryhmään kuulumisen ilmaisu (esim. Bakker 1995: 138; Granqvist 2013a: 104, 2013b: 167; Matras ym. 2007: 32-38). Pararomanit ovat ryhmänsisäisen viestinnän väline, ja jotkin niistä ovat apuna häveliäisyyteen liittyvien ja vältettävinä pidettyjen aiheiden ilmaisemisessa - koodinvaihto yleiskielestä pararomaniksi on ikään kuin kiertoilmaisua (vrt. Bakker 1995: 138; Matras ym. 2007: 32-38; Granqvist 2013b: 167, 172). Borezkyn ja Iglan (1994) ja Hedmanin (2004, 2009) mukaan myös Suomessa romanit haluavat säilyttää romanikieleen pohjautuvaa sanastoa ryhmän sisäistä viestintää varten. Pararomanien sanastoa on paikoin myös muiden kuin romanien käytössä (Bakker 1995: 138-139; Eztler 1944: 200-205; Matras 2010: 2). Suomessa romanikielen leksikkoa on dokumentoitu romanien käyttämien kielimuotojen lisäksi erilaisiin slangisanakirjoihin (Lipsonen 1990; Urbaani sanakirja 2010). Brittein saarten romaneilla on käytössään myös muiden etnisten ryhmien sanoja salakielifunktiossa (Matras 2010: 2).

Hancock $(1970,1976)$ on luokitellut angloromanin kreoliksi, useammasta kielestä sulautuneeksi kieleksi, ja esimerkiksi Kenrick (1979) puolestaan englannin varieteetiksi. Boretzky ja Igla (1994) ovat sen sijaan määritelleet pararomanit romanikielen sekamurteiksi. Brittein saarten angloromani täyttää pararomaniksi määrittelyn edellytykset, koska sillä on englannin rakenne ja lähinnä vain sanastoa romanikielestä. Romanikieltä sisältävä suomi muistuttaa rakenteellisesti monessa suhteessa angloromania ja Pohjoismaiden skandoromania (Hancock 1992; Vuorela \& Borin 1998; Pirttisaari 2002; Granqvist 2011, 2012), ja sitä onkin kutsuttu fennoromaniksi. Suomessa on kuitenkin yhä elossa myös niin sanottu taivutettu romanikieli (kaalengo tšimb 'romanien kieli') toisin kuin esimerkiksi Iberian niemimaalla, Skandinaviassa ja Brittein saarten pohjoisosissa puhutuissa murteissa. Taivutetulla romanikielellä tarkoitetaan romanilingvistiikassa kieltä, jossa on säilynyt romanikielen kieliopillinen rakenne.

\footnotetext{
17. Ruotsin rommani 'romanikieli', Norjan romani 'romanikieli'; lisäksi käytetään muitakin termejä, kuten romani rakripa'romanipuhe'. 
Pararomanin sijasta kuitenkin etnolekti (Vuorela \& Borin 1998: 68) voisi olla parempi luonnehdinta ottaen huomioon romanikieltä sisältävän suomen ja pararomanien erot. Tällainen romanikieltä sisältävä suomi on kahta kieltä osaavien kielimuoto, jota luonnehtii se, että kummankin kielen taito vaihtelee eri puhujien ja kirjoittajien välillä. Romanikieliset elementit eivät ole kuitenkaan ainoa tekijä, jonka perusteella Suomen romanien keskenään käyttämää suomen kielimuotoa voi kutsua etnolektiksi. Tämä varieteetti eroaa nimittäin monella kielen tasolla muiden väestöryhmien käyttämästä suomen kielestä, vaikka romanikielisiä elementtejä ei käytettäisikään. ${ }^{18}$ Tämä tutkimus tuo luonnehdinnan avuksi verkkokeskustelujen kielen. Tulokset osoittavat, että vaikka verkkokeskustelussa käytetään suomen seassa ennen muuta yksittäisiä romanikielisiä sanoja ja ilmeisesti fraaseina opittuja ilmaisuja, keskustelijoiden parissa osataan myös romanikielen taivutusta. Näissä keskusteluissa on käytössä romanikielen sanastoa ja kieliopillisia rakenteita sisältävän suomen varieteetin lisäksi myös taivutettu romanikieli, jota useampi romanikeskustelija ymmärtää ja osaa käyttää.

\section{Yhteenvetoa ja pohdintaa}

Olen esitellyt tässä artikkelissa romanikielisiä elementtejä sisältävää suomenkielistä verkkokeskustelua sen romanikielisen leksikon ja taivutuksen osalta. Tarkasteluni osoittaa Suomen romanien verkkokeskustelun kielen olevan monessa suhteessa samankaltaista kuin romanien keskinäisen suomenkielisen puhutun keskustelun kieli (vrt. Granqvist 2009; Granqvist \& Viljanen 2002; Hedman 2004, 2009; Åkerlund 2004). Tätä romanikieltä sisältävää suomea voi kutsua etnolektiksi, jota käytetään nimityksenä etnisen ryhmän käyttämästä kielen varieteetista. Romanikielisiä elementtejä sisältävä etnolekti on käytössä myös romanien verkkokeskustelussa. Suomen romanien suomen kielen varieteetti on verkkokeskusteluympäristössä paljolti samassa käytössä kuin puhutussa keskustelussa, sillä se on romanien keskinäisen keskustelun tuntomerkki ja jossakin määrin salakieli. Sen käyttöalueet ovat romanien välinen keskustelu sekä tilanteet, joissa on mukana sekä romaneja että valtaväestön edustajia. Salakielikäyttöä esiintyy leimallisesti jälkimmäisessä tilanteessa. Romanien viesteissä, jotka on suunnattu yksinomaaan valtaväestön edustajille, vältetään yleensä romanikielisten elementtien käyttöä. Romanikieltä käytetään myös tervehdyksiin, interjektioihin ja korvaamaan tilapäisesti suomenkielisiä sanoja - samaan tyyliin kuin muita vieraita kieliä, etenkin englantia, käytetään suomenkielisessä verkkokeskustelussa.

Analyysini osoittaa, että vähintään kymmenen kertaa suomenkielisissä lauseissa esiintyvistä romanikieleen perustuvista lekseemeistä yli puolet (19/33) on substantiiveja. Näistä kahdeksan ilmaisee etnistä alkuperää akselilla romani - muu kuin romani. Nämä sanat ovat indoarjalaista alkuperää kuten myös useimmin käytetyt pronominit

18. Kuvaavia esimerkkejä romanien käyttämän suomen erityispiirteistä ovat heidän keskinäisissä keskusteluissa käyttämänsä ilmaisut toisten kanssa ja muille puhuu merkityksessä 'omien vanhempieni kanssa' ja 'puhua aviomiehelleen' sekä eräiden adjektiivien suosiminen (esim. rankka ja ankara ja niiden genetiivimuodot merkityksessä 'erittäin') ja puheen omaleimainen prosodia. 
koon 'kuka' ja me 'minä. Substantiivien valta-asema romanikieleen perustuvassa sanastossa noudattaa lainautumisesta havaittuja yleisiä lainalaisuuksia (Granqvist 2013a: 120-121; Schmidt \& de Bot 2004: 215). Aineiston suomenkielisissä lauseissa esiintyy kuitenkin kaikkia romanikielen sanaluokkia, substantiivien jälkeen eniten adjektiiveja ja verbejä. Ainoastaan romanikielen numeraalit puuttuvat suomenkielisistä lauseista; lukusanoja esiintyy vain kerran sanaluettelossa. Ilmiötä voi verrata havaintoihin romanikielen numeraalien taidon heikkenemisestä Suomessa (Granqvist 2013a: 126). Vaikka romanikielinen sanavarasto on keskustelupalstalla suppea, miltei kaikki romaneiksi ilmoittautuvat kirjoittajat käyttävät vähintään paria yleisimmin käytettyä romanikieleen perustuvaa sanaa kommenteissaan. Sanojen taivutuksessa on molemminpuolista vaikutusta suomen ja romanikielen välillä, mutta romanikieleen pohjautuvien sanojen mukauttaminen suomen kielen kielioppiin on kuitenkin niiden yleisin taivutustapa. Yksilöllinen variaatio on runsasta, mitä on yleisesti pidetty yhtenä kielen rapautumisen merkkinä (Lindgren 1993: 9). ${ }^{19}$ Verkkokeskusteluissa variaatio ilmenee sanojen kirjoitusasussa esiintyvänä vaihteluna.

Huomattavan suuri osuus verkkokeskusteluaineiston romanikielisestä sanastosta periytyy sanskritista ja prakritista ja on yhteistä juurta hindin sanaston kanssa. Kuten edellä on käynyt ilmi, tätä juurta ovat myös useimmat romania ja muuta kuin romania merkitsevät sanat, jotka ovat aktiivisimmin käytettyä romanikieleen perustuvaa sanastoa suomenkielisessä verkkokeskustelussa. Etnisen ryhmän ilmaiseminen romanikielellä on yleistä ilmeisesti sen sosiaalisen merkityksen vuoksi.

Olen myös verrannut tuloksiani Suomen romanien verkkokeskustelusta pararomaneihin ja pararomanin käsitteeseen. Suomen romanien etnolekti sisältää pararomanin tavoin romanikielisiä elementtejä, etenkin sanastoa. Yhteistä muiden pararomanien, varsinkin angloromanin, kanssa ovat myös romanikieleen perustuvien sanojen käyttötarkoitukset. Näitä ovat salakielifunktio ja etnisen identiteetin esiintuonti. Kielimuodoille yhteistä on avainsanojen vaihtaminen romanikieleen perustuviksi sanoiksi. Avainsanoilla tarkoitan sanoja, jotka vaihtamalla viestin salattavan sisällön voi kätkeä tai kulttuurinsisäisen merkityksen saa ilmaistua. Suomen romanien suomea ja romanikieltä sekoittava kielimuoto on kuitenkin dynaamista ja vaihtelevaa romanikielestä lainaamisen ja muun romanikielisten elementtien käytön osalta. Tutkimustulokseni osoittavat, että Suomen romanien verkkokeskustelussa ilmenee vaihtelua taivutetun romanikielen ja suomen kielen tai romanien suomen etnolektin välillä; lisäksi suomenkielisen keskustelun lomassa esiintyy myös koodinvaihdonomaisesti romanikielisiä rakenteita. Nämä seikat osoittavat, että Suomen romanikieli ei ole kielimuotona kuollut verkkokeskusteluympäristössäkään eikä korvautunut pararomanilla. Lainaaminen suomen ja romanikielen välillä vaihtelee yksilöittäin. Jotkin romanikieleen perustuvat sanat esiintyvät usealla eri kirjoittajalla, vaikka niiden käyttöön ei ole erityistä syytä sanojen sisällön vuoksi (esimerkiksi sana h̆oh̆av- > hoha-ta 'valehdella'). Tämä osoittaa, että taivutetusta romanikielestä, joka on yhä puhuttu kieli Suomessa, otetaan

19. Lindgrenin (1993: 9) mukaan yhteisön monikielisyys voi vaikuttaa myös kieliyhteisön kontrollin luonteeseen siten, että innovaatioita ja variaatiota aletaan sallia aiempaa helpommin, jolloin kielen muutos nopeutuu. 
innovatiivisesti käyttöön sanastoa ja rakenteita suomenkieliseen keskusteluun. Siten Suomen romanien suomen kielen varieteetti ei ole määriteltävissä pararomaniksi. Tutkimastani verkkokeskustelusta voi päätellä, että kirjoittajilla on motivaatiota kirjoittaa romanikielellä ja käyttää romanikielisiä elementtejä varsinkin tietyissä yhteyksissä. Romanikielen harvinaistuminen käyttökielenä näkyy kuitenkin sanavaraston suppeutena ja muutoinkin kielitaidon rajoittuneisuutena.

\section{Aineistolähteet}

Suomi24.fi-Romano. Erillinen keskusteluryhmä Suomi24.fi-sivustolla. https://keskustelu. suomi24.fi/ryhmat/romano (18.9.2016).

\section{Lähteet}

Adamou, Evangelia - Granqvist, Kimmo 2015: Unevenly mixed Romani languages. - International Journal of Bilingualism 19 s. 525-547. http://journals.sagepub.com/doi/ pdf/10.1177/1367006914524645.

Arminen, Ilkka 2016: Teknologiset ympäristöt. - Melisa Stevanovic \& Camilla Lindholm (toim.), Keskustelunanalyysi. Kuinka tutkia sosiaalista toimintaa ja vuorovaikutusta s. 178-199. Tampere: Vastapaino.

Auer, Peter 1999: From code-switching via language mixing to fused lects. Toward a dynamic typology of bilingual speech. - International Journal of Bilingualism 3 s. 309-332.

BAkker, Peter 1995: Genesis of Caló and other Iberian Para-Romani varieties. - Yaron Matras (toim.), Romani in contact s. 125-150. Amsterdam: John Benjamins.

Borezky, Norbert 1998: Der Romani-Wortsatz in der Romani-Misch-Dialekten (Pararomani). - Yaron Matras (toim.), The Romani element in non-standard speech s. 97-132. Wiesbaden: Harrossowitz.

Borezky, Norbert - Igla, Birgit 1994: Romani mixed dialects. - Peter Bakker \& Maarten Mous (toim.), Mixed languages. 15 case studies in language intertwining s. 36-68. Amsterdam: Instituut voor de Functionale Onderzoek van Taal en Taalgebruik.

Clyne, Michael - Eisikovits, Edina - Tollfree, Laura 2002: Ethnolects as in-group varieties. - Anna Duszak (toim.), Us and others. Social identities across languages, discourses and cultures s. 133-157. Amsterdam: John Benjamins.

Cortiade, Marcel 1991: Romani versus Para-Romani. - Peter Bakker \& Marcel Cortiade (toim.), In the margin of Romani. Gypsy languages in contact s. 1-15. Studies in Language Contact I. Amsterdam: Institute for General Linguistics.

Eztler, Allan 1944: Zigenarna och deras avkomlingar i Sverige. Historia ock språk. Stockholm studies in Scandinavian Philology 4. Uppsala: Almqvist \& Wiksell.

GANANDER, KRISTFRID 1780: Undersökning om De så kallade TATTARE eller Zigeuner, Cingari, Bohemiens, Deras härkomst, Lefnadssätt, språk m.m. Samt om, när och hwarest några satt sig ner i Swerige? Käsikirjoitus. Stockholm: Vitterhetsakademien.

GRANQVIST KImmo 2007: Suomen romanin äänne- ja muotorakenne. Suomen Itämaisen Seuran suomenkielisiä julkaisuja 36. Kotimaisten kielten tutkimuskeskuksen julkaisuja 145. Helsinki: Suomen Itämainen Seura ja Kotimaisten kielten tutkimuskeskus.

_ 2009: Mikä on erilaista romanien diskurssissa? - Anna Idström \& Sachiko Sosa (toim.), Kie- 
lessä kulttuurien ääni s. 206-222. Tietolipas 228. Helsinki: Suomalaisen Kirjallisuuden Seura.

— 2011: Romanikieli, fennoromani ja suomi. Esitelmä Kielitieteen päivillä. Joensuu, 25.27.5.2011.

2012: Metaphors of the Finnish Roma in Finnish and Romani. - Anna Idström \& Elisabeth Piirainen (toim.), Endangered metaphors s. 293-314. Cognitive Linguistic Studies in Cultural Contexts 2. Amsterdam: John Benjamins.

_ 2013a: Attritio ja itsearviointi. Morfosyntaktinen attritio Suomen romanikielessä. - Kimmo Granqvist \& Päivi Rainò (toim.), Rapautuva kieli. Kirjoituksia vähemmistökielten kulumisesta ja kadosta s. 103-148. Suomalaisen Kirjallisuuden Seuran Toimituksia 1404. Helsinki: Suomalaisen Kirjallisuuden Seura.

- 2013b: Romanikielen taidon heikkeneminen ja pararomani. - Kimmo Granqvist \& Mirkka Salo (toim.), Romanikieli ja sen tutkimusalat s. 164-194. Suomalaisen Kirjallisuuden Seuran Toimituksia 1268. Helsinki: Suomalaisen Kirjallisuuden Seura.

Granqvist, Kimmo - Pirttis Aari, Helena 2003: Suomen romanin leksikaalisista kerrostumista ja niiden fonologisista ja morfologisista prosesseista. - Puhe ja kieli 1/2003 s. 25-41.

Granqvist, Kimmo - Viljanen, Anna-Maria 2002: Kielelliset tabut romanien puheessa. - Sirkka Laihiala-Kankainen, Sari Pietikäinen \& Hannele Dufva (toim.), Moniääninen Suomi s. 109-125. Jyväskylän yliopiston Soveltavan kielentutkimuksen keskus.

Hancock, IAn 1970: Is Anglo-Romanes a creole? - Journal of the Gypsy Lore Society 49 s. 41-44.

1976: The pidginization of Angloromani. - George Cave (toim.), New directions in creole studies, s. 1-23. Georgetown: University of Guyana.

- 1992: The social and linguistic development of Scandoromani. - Ernst H. Jahr. (toim.), Language contact. Theoretical and empirical studies s. 37-52. Berlin: Mouton de Gruyter.

Hedman, Henry 2004: Suomen romanikielen salakielifunktio. - Marja Nenonen (toim.), Papers from the 3oth Finnish conference of linguistics: Joensuu, May 15-16, 2003 s. 42-48. Kielitieteellisiä tutkimuksia 39. Joensuu: Joensuun yliopisto.

— 2009: Suomen romanikieli: sen asema yhteisössään, käyttö ja romanien kieliasenteet. Kotimaisten kielten tutkimuskeskuksen verkkojulkaisuja 8. Helsinki: Kotimaisten kielten tutkimuskeskus. http://scripta.kotus.fi/www/verkkojulkaisut/julk8/ (10.7.2017).

Helasvuo, Marja-Liisa - Johansson, Marjut - Tanskanen, Sanna-Kaisa (toim.) 2014: Kieli verkossa. Näkökulmia digitaaliseen vuorovaikutukseen. Helsinki: Suomalaisen Kirjallisuuden Seura.

Idäntutkimus 3/2015. Romanit s. 1-61.

ISK = Hakulinen, Auli - Vilkuna, Maria - Korhonen, Rittta - Koivisto, Vesa - Heinonen, Tarja Rittta - Alho, Irja 2004: Iso suomen kielioppi. Helsinki: Suomalaisen Kirjallisuuden Seura.

KALliokosKi, JyRKi 1995: Koodinvaihto ja keskustelun moniäänisyys. - Virittäjä 99 s. 2-24.

KENRICK, DONALD 1979: Romani English. - International Journal of Sociology of Language 19 s. 111-12O.

Kotilainen, LaRi 2008: Englanti suomenkielisissä chat-keskusteluissa. - Tiina OnikkiRantajääskö \& Mari Siiroinen (toim.), Kieltä kohti s. 128-144. Helsinki: Otava.

Kovanen, Petra 2010: Koodinvaihtelu romanikielisessä keskustelussa. Pro gradu -tutkielma. Helsingin yliopiston suomen kielen laitos.

2013: Koodinvaihtelu romanikielessä. - Kimmo Granqvist \& Mirkka Salo (toim.), Romanikieli ja sen tutkimusalat s. 195-216. Suomalaisen Kirjallisuuden Seuran Toimituksia 1268. 
Helsinki: Suomalaisen Kirjallisuuden Seura.

Lindgren, Anna-Riitta 1993. Miten muodot muuttuvat. Ruijan murteiden verbintaivutus Raisin, Pyssyjoen ja Annijoen kveeniyhteisöissä. Tromssan yliopisto: Kielten ja kirjallisuuden laitos.

LiPSONEN, LEO 1990: Vankilaslangin sanakirja. Vankeinhoidon koulutuskeskuksen julkaisuja 2/199o. Helsinki: VAPK-kustannus.

Matras, YARON 2010: Romani in Britain. The afterlife of the language. Edinburgh: Edinburgh University Press.

Matras, Yaron - Gardner, Hazel - Jones, Charlotte - Schulman, VeroNICA 2007: Angloromani. A different kind of language? - Anthropological Linguistics 49 S. $142-184$.

Meakins, Felicity 2013: Mixed languages. - Peter Bakker \& Yaron Matras (toim.), Contact languages s. 159-228. Berlin: Walter de Gruyter.

MuIR, Simo 2009: Jiddišistä ruotsin kautta suomeen: Helsingin juutalaisten kielenvaihdoista ja etnolektistä. - Virittäjä 113 s. 533-556.

_ 2013: Jiddišistä suomenjuutalaisten etnolektiksi. - Kimmo Granqvist \& Päivi Rainò (toim.), Rapautuva kieli. Kirjoituksia vähemmistökielten kulumisesta ja kadosta s. 149-172. Suomalaisen Kirjallisuuden Seuran Toimituksia 1404. Helsinki: Suomalaisen Kirjallisuuden Seura.

Muysken, Pieter - Rott, Julian 2013: Ethnolect studies in the German and the Netherland area. An overwiew. - Peter Siemund, Ingrid Gogolin, Monika Edith Schulz \& Julia Davydova (toim.), Multilingualism and language diversity in urban areas. Acquisition, identities, space, education s. 177-208. Amsterdam: John Benjamins.

Myers-SCOTton, CAROL 2002: Contact linguistics, bilingual encounters and grammatical outcomes. Oxford: Oxford University Press.

NordQvist, Richard 2017: Double plurals in English. Glossary of grammatical and rhetorical terms. Päivitetty 22.9.2017. https://www.thoughtco.com/double-plural-grammar-1690409 (1.12.2017).

Paunonen, Heik ki 2006: Synonymia Helsingin slangissa. - Virittäjä 110 s. 336-364.

2017: Tsennaaks Stadii, bonjaaks slangii. Stadin slangin suursanakirja. 6. painos. Jyväskylä: Docendo.

Pirttisa ari, Helena 2002: Suomen romanin partisiippien morfologiaa. Pro gradu -tutkielma. Helsingin yliopiston yleisen kielitieteen laitos.

2004: Contact-induced changes in Finnish Romani. Passive voice. http://www.ling.helsinki.fi/uhlcs/LENCA/LENCA-2/information/datei/29-pirttisaari.pdf.

Poplack, Shana 1980:"Sometimes I'll start a sentence in English Y TERMINO EN ESPANOL". Towards a typology of code-switching. - Linguistics 18 s. 581-618.

_ 2004: Code-switching. - Ulrich Ammon, Norbert Dittmar, Klaus J. Mattheier \& Peter Trudgill (toim.), Sociolinguistics. An international handbook of the science of language and society s. 585-596. 2. painos. Berlin: Walter de Gruyter.

Pulma, Panu (toim.) 2006: Suljetut ovet - Pohjoismaiden romanipolitiikka 150o-luvulta EUaikaan. Helsinki: Suomalaisen Kirjallisuuden Seura.

SALO, MirkKA 2016: Romanikielisten lainasanojen ja koodinvaihdon tehtävät suomen romanien suomenkielisessä verkkokeskustelussa. - Puhe ja kieli 4/2016 s. 251-271.

Schmidt, Annette - De Bot, Kees 2004: Language attrition. - Alan Davies \& Catherine Elder (toim.), The handbook of applied linguistics s. 210-234. Oxford: Blackwell.

Sollid, Hilde 2013: Ethnolects in Northern Norway. From national negligence to local 
linguistic pride. - Peter Siemund, Ingrid Gogolin, Monika Edith Schulz \& Julia Davydova (toim.), Multilingualism and language diversity in urban areas. Acquisition, identities, space, education s. 63-94. Amsterdam: John Benjamins.

Thesleff, A. 1911: Report on the Gypsy problem. - Journal of the Gypsy Lore Society, New Series Vol. 5 s. 81-107, 218-224, 255-269.

Tikkanen, Bertil 2013: Romanikielen intialaiset juuret. - Kimmo Granqvist \& Mirkka Salo (toim.), Romanikieli ja sen tutkimusalat s. 38-76. Suomalaisen Kirjallisuuden Seuran Toimituksia 1268. Helsinki: Suomalaisen Kirjallisuuden Seura.

Urbaani Sanakirja. Suomen suurin slangisanakirja. https://www.urbaanisanakirja.com/word/ (20.4.2016).

Valtonen, Pertti 1968: Suomen mustalaiskielen kehitys eri aikoina tehtyjen muistiinpanojen valossa. Lisensiaatintutkimus. Helsingin yliopiston Aasian ja Afrikan kielten laitos.

— 1972: Suomen mustalaiskielen etymologinen sanakirja. Tietolipas 79. Helsinki: Suomalaisen Kirjallisuuden Seura.

Vuorela, Katri - Borin, Lars 1998: Finnish Romani. - Ailbe Ó. Corráin \& S. Mac Mathúna (toim.), Minority languages in Scandinavia, Britain and Ireland s. 51-76. Acta Universitatis Upsaliensis. Studia Celtica Upsaliensia 3. Uppsala.

Woolgar, Steve 1991: Configuring the user. The case of usability trials. - John Law (toim.), A sociology of monsters. Esseys on power, technology and domination s. 58- 9. London: Routledge.

Åkerlund, Anet te 2004: Romaninuorten kieli Suomessa - Marja Nenonen (toim.), Papers from the 3oth Finnish conference of linguistics. Joensuu, May 15-16, 2003 s. 237-239. Kielitieteellisiä tutkimuksia 39. Joensuu: Joensuun yliopisto.

\section{Liite}

\section{Lyhenteet $^{20}$}

$\begin{array}{ll}4 & \text { passiivin persoonapääte } \\ \text { ABL } & \text { ablatiivi } \\ \text { ADJ } & \text { adjektiivi } \\ \text { ALL } & \text { allatiivi } \\ \text { ap. } & \text { apabhramiśa } \\ \text { arb. } & \text { arabia } \\ \text { arm. } & \text { armenia } \\ \text { ašk. } & \text { aškũ l. aškund (kāfir) } \\ \text { ass. } & \text { assāmī } \\ \text { baš. } & \text { baškarīk (dard.) } \\ \text { ben. } & \text { bengālī } \\ \text { CLI } & \text { liitepartikkeli } \\ \text { COMP } & \text { komplementoija }\end{array}$

20. Luettelo sisältää myös verkkoliitteen taulukoissa olevat lyhenteet. 


\begin{tabular}{|c|c|}
\hline COND & konditionaali \\
\hline dam. & dameli (kāfir) \\
\hline dar. & dardikielet \\
\hline DAT & datiivi \\
\hline DER & johdin \\
\hline ḍum. & ḍumāki \\
\hline ear. & esiarjalaiset kielet \\
\hline ELA & elatiivi \\
\hline $\mathrm{F}$ & feminiini \\
\hline gab. & gawar-bati (kāfir) \\
\hline GEN & genetiivi \\
\hline ger. & germaaniset kielet \\
\hline guj. & gujarāti \\
\hline hin. & hindi \\
\hline ILL & illatiivi \\
\hline IMP & imperatiivi \\
\hline IND & indikatiivi \\
\hline INF & infinitiivi \\
\hline INS & instrumentaali \\
\hline INSTR & instruktiivi \\
\hline it. & italia \\
\hline kas. & keskialasaksa \\
\hline kbe. & keskibengali \\
\hline kur. & kurdi l. kurmāndžī \\
\hline kys. & keskiyläsaksa \\
\hline luett. & esiintyy sanaluettelossa \\
\hline lät. & lätti \\
\hline M & maskuliini \\
\hline mag. & māgadhī \\
\hline mai. & maithilī \\
\hline mar. & marāṭ̂hī \\
\hline msl. & muinaislaavi \\
\hline mun. & mundā-kielet \\
\hline mur. & murre, murteet \\
\hline NEG & negaatio \\
\hline nep. & nepālī \\
\hline nkr. & nykykreikka \\
\hline no. & nykynorja \\
\hline nr. & nykyruotsi \\
\hline nt. & nykytanska \\
\hline OBL & obliikvi \\
\hline or. & oṛiyā \\
\hline pah. & pahāṛī \\
\hline pañ. & pañjābī \\
\hline
\end{tabular}




\begin{tabular}{|c|c|}
\hline PAR & partitiivi \\
\hline paš. & pašai (dard.) \\
\hline PASS & passiivi \\
\hline per. & persia \\
\hline pha. & phalūṛa (dard.) \\
\hline pkt. & prakrit \\
\hline PL & monikko \\
\hline PRS & preesens \\
\hline РРТСР & passiivin partisiippi \\
\hline PRT & preteriti \\
\hline РТСР & partisiippi \\
\hline pu. & puola \\
\hline rma. & romania \\
\hline rom. & romani \\
\hline sa. & saksa \\
\hline sav. & savī (dard.) \\
\hline sbk. & serbokroatia \\
\hline ser. & serbia \\
\hline SG & yksikkö \\
\hline $\sin$. & sindhī \\
\hline sit. & sitaattilainaus \\
\hline ska. & skandinaaviset kielet \\
\hline skt. & sanskrit \\
\hline sl. & slaavilaiset kielet \\
\hline slo. & slovakki \\
\hline su. & suomi \\
\hline SUFF & possessiivisuffiksi \\
\hline tir. & tirāhī (dard.) \\
\hline tš. & tšekki \\
\hline tur. & turkki \\
\hline $\begin{array}{l}\text { u. rom. } \\
\text { unk. }\end{array}$ & $\begin{array}{l}\text { ulkomainen romanimurre, ulkomaiset romanimurteet } \\
\text { unkari }\end{array}$ \\
\hline $\begin{array}{l}\text { W. rom. } \\
\text { ve. }\end{array}$ & $\begin{array}{l}\text { Walesin romanimurre } \\
\text { venäjä }\end{array}$ \\
\hline
\end{tabular}

\section{Verkkoliite}

Ks. artikkelin verkkoversio osoitteessa https://journal.fi/virittaja. 


\section{Romani and Romani-based words and structures in Finnish-language online communication by the Finnish Roma}

This article investigates the use of Romani and Romani-based words in Finnish-language online discussions within the Finnish Roma community. The data encompasses the entire archive of the online discussion board Suomi24.fi-romano from between 22.2.2003 and 18.7.2013. The aim of this study is to compare the online communications of the Finnish Roma to their spoken contemporary language. I also compare the ethnolect of the Finnish Roma against the definition of Para-Romani. Para-Romanis have the grammatical structure of another language and only employ the vocabulary of Romani. For describing this special Finnish variety - the ethnolect - the article examines the origin, the use of parts of speech, and the inflection of Romani lexemes in Finnishlanguage sentences.

The analysis reveals that in their online communications the Finnish Roma use both Finnish and Romani but also a variety of Finnish featuring words, grammatical forms and sentences based on Romani. The vocabulary based on Romani is taken from up to seventeen different language groups, most of them examples of the historical Indo-Arian languages. The effect of contact languages is considerably smaller, and the most common influences are from the Scandinavian languages. Romani-based words are used in several inflected forms of Finnish and Romani grammar. Some words include structures of both languages.

All parts of speech occur at least once in Romani-based vocabulary, but nouns are notably the most common word class. This is a typical phenomenon in borrowing. The Romani vocabulary present in Finnish comments in the corpus of data is narrow, and the use of Romani words varies individually. These facts are generally an indication of weakening language skills and a decrease in the use of the language. However, the construction of Romani-based or Romani-mixed words in online discussions is very creative. The ethnolect of the Finnish Roma also takes grammatical linguistic elements from the inflected Romani language. Thus, the definition of Para-Romani does not fit the ethnolect used in the online communications of the Finnish Roma. 


\section{Romanikielinen ja romanikieleen pohjautuva aines Suomen romanien suomenkielisessä verkkokeskustelussa}

Artikkeli tarkastelee romanikielisten ja romanikieleen pohjautuvien sanojen käyttöä Suomen romanien suomenkielisessä verkkokeskustelussa. Aineistona ovat verkkokeskustelupalsta Suomi24.fi-romanon tekstit ajalta 22.2.2003-18.7.2013. Tutkimusmetodina on aineiston empiirinen tarkastelu. Tutkimuksen tavoitteena on verrata Suomen romanien verkkokeskustelun kieltä heidän puhuttuun kieleensä, josta on tehty aiempaa tutkimusta. Tätä suomen kielen varieteettia, jossa ilmenee myös romanikielisiä aineksia, kutsutaan etnolektiksi. Lisäksi pohditaan sitä, sopiiko pararomanien määrittely Suomen romanien suomen varieteettiin. Pararomaneilla tarkoitetaan kielimuotoja, joista on kadonnut romanikielen kielioppi. Tutkimuksessa tarkastellaan myös romanien suomen kielen varieteetissa esiintyvien romanikielisten elementtien alkuperää, sanaluokkajakaumaa ja taivutusta.

Aineiston tarkastelu osoittaa, että Suomen romanit käyttävät verkkokeskustelussa suomen yleis- ja puhekielen ja Suomen romanikielen lisäksi sellaista suomen varieteettia, jossa on romanikieleen perustuvia sanoja, kieliopillisia muotoja ja lauseita. Aineiston romanikieleen pohjautuva sanasto on alkuperältään monipuolista. Suurin osa lekseemeistä perustuu historialliseen indoarjalaiseen sanastoon. Kontaktikielten vaikutusta on huomattavasti vähemmän, yleisimpinä skandinaaviset vaikutteet. Sanoja taivutetaan useissa eri taivutusmuodoissa sekä suomen että romanikielen kieliopin mukaan. Joissakin sanoissa on molempien kielten taivutuksen aineksia. Kaikki sanaluokat esiintyvät vähintään kerran, mutta substantiivit ovat selvästi yleisimpiä. Suomenkielisten kommenttien romanikielinen sanasto on suppeaa, ja sen käyttö vaihtelee yksilöllisesti. Nämä seikat kertovat yleensä kielitaidon ja kielen käytön yleisestä vähenemisestä, mutta toisaalta sanojen muodostaminen on verkkokeskustelussa luovaa. Taivutetusta Suomen romanikielestä otetaan käyttöön uusia, myös kieliopillisia romanikielisiä elementtejä. Siten verkkokeskustelussa käytettyyn romanien etnolektiin ei sovi pararomanin määrittely.

Kirjoittajan yhteystiedot (address):

etunimi.sukunimi@helsinki.fi 